\title{
Postmodern Dönemde Türkiye'de Sosyolojik Olarak Turizm-Din İlişkisi
}

\author{
Muhammed Yamaç \\ Dr., Diyanet İşleri Başkanlığ1 \\ Dr., The Presidency of Religious Affairs \\ Eskisehir/Turkey \\ yamacmuhammed@hotmail.com \\ ORCID: 0000-0003-2215-4492
}

\section{Sociologically the Relationship Between Tourism and Religion in Turkey in the Postmodern Period Abstract}

Tourism is one of the space where religion gained visibility in the postmodern period. In this aspect, tourism in Turkey has important sociological content in terms of reflecting the public/social postmodernist view of religion. Religious tourism and Islamic holiday concept are the most dynamic examples of this visibility. Fort this reason, the relationship between tourism and religion is an important research sphere that needs to be studied from the point of view of sociology of religion. The research attempts to examine the relationship between tourism and religion in Turkey in the postmodern period. In this context, it tries to examine and make sense of what kind of changes and transformations religion and religiosity have undergone in the fields of tourism in the postmodern period. In this context; "what are the postmodern dimensions of the relationship between religion and tourism? What kinds of changes have emerged in the articulation of religion to tourism? In which fields of tourism and in what ways do these changes gaining visibility? How did tourism affect religion and religiosity in the postmodern era? What is the appearance of religion in tourism and what is its function in the postmodern process?" etc. focused on the problems. The study attempts to understand and make sense of this problem of the subject from a sociological of perspective. The research is based on the analysis of data/findigs obtained through indirect observation on documents that directly or indirectly examine the relationship between tourism and religion.

The relationship between tourism and religion appears in two different views in Turkey, mainly in the form of "religious tourism" and "Islamic holiday". In both tourism spaces, it comes to the fore in relation to religious motifs that differ with traditional life in the context of postmodernist tendencies and changes. At this point, both religious tourism and Islamic holidays carry important social indicators that embody the postmodern view in a section of religion and religious lifestyle (in daily practices). Due to this postmodern view, aspects and contents emerge in which a complex, paradoxical and comsumption-oriented style becomes clear in the daily life of the religious middle class. From this point of view, these touristic spaces in question offer the opportunity to depict both the relationship between tourism and religion, the attitude and behavior interaction between tourism

Intihal Taraması/Plagiarism Detection: Bu makale intihal taramasından geçirildi/This paper was checked for plagiarism Etik Beyan/Ethical Statement: Bu çalışmanın hazırlanma sürecinde bilimsel ve etik ilkelere uyulduğu ve yararlanılan tüm çalışmaların kaynakçada belirtildiği beyan olunur/It is declared that scientific and ethical principles have been followed while carrying out and writing this study and that all the sources used have been properly cited (Muhammed Yamaç).

Geliş/Received: 01 Aralı/December 2020 | Kabul/Accepted: 25 Şubat/Fabruary 2021 | Yayın/Published: 20 Mart/March 2021 Attf/Cite as: Muhammed Yamaç, "Postmodern Dönemde Türkiye'de Sosyolojik Olarak Turizm-Din İlişkisi = Sociologically the Relationship Between Tourism and Religion in Turkey in the Postmodern Period", Eskiyeni 43 (Mart/March 2021), 237267. https://doi.org/10.37697/eskiyeni.834340

CC BY-NC 4.0 | This paper is licensed under a Creative Commons Attribution-NonCommercial License 
and religiosity, and within this framework, the approach of the religious people to postmodern consumption practices with different aspects and dimensions. In this picture, religion, religiosity and consumption contain a public/social sphere intertwined.

As part of religious tourism, in organizations of pilgrimage, umrah, visiting sacred places, etc., it can be observed that a postmodern trend that classesalizes/differentiates religious segments in the VIP/luxury type and divides them into rich-poor gradually increases their visibility in religious life. In the context of the Islamic holiday, it is seen that the all-inclusive (relatively Islamic) holiday type that encourages unlimited consumption in the five star (luxury) status, which stands out as an important aspect of integrating into the postmodern consumer society, becoming more widespread in the postmodern period. It this sense, it can be seen that the mentioned touristic spaces shape the religious (middle) class within the framework of the decisive of postmodern consumption. In addition, in this postmodernist touristic view, religion, religious values, symbols and concepts are marketized, alienated, commodified, instrumentalized with a legitimizing function and transformed into a consumption object in this sense as part of the global cultural industry. In this sense, religion, religious values, symbols and concepts are detached from their traditional structure and presented in an attractive way to the liking/benefit of religious people in a postmodernist view. This reveals new attitudes, situations or developments that are against the basic principles of Islam and traditional interpretations and practices. The postmodern view of both tourism field based on consumption, contradicts the perspective of waste (extravagance) that Islam describes as haram and the balanced (moderate) life it proposes. As a matter of fact, Islam advises the individual to avoid extremes in daily life and to lead a balanced lifestyle. It can be observed that the tension, conflict and paradox between religion and postmodernity increase when this balance is disrupted and commitment to the secular increases.

As a decisive effect of the postmodernist consumption trend in the field of Islamic holiday and religious tourism, it is possible to accept the existence of a change in religion and religiosity in Turkey that will allow integration into the secular/capitalist system. However, this situation does not change the fact that in postmodern era, Islam preserves and maintains its importance and existence to a great extent with its new social/public view. As a matter of fact, despite the unlimited, insatiable and irresponsible consumption incentives of postmodern life practices/culture, religion continues to exist as the most important factor that draws attention to a simple, natural and contentious (abstemious) life and the transience of the world. In this sense, it can be said that religion contains the strongest system against the consumption and pleasure-oriented postmodernist tendencies and secular structures seen in tourism.

\section{Keywords}

Sociology of Religion, Religion, Tourism, Postmodern Period, Turkey

\section{Postmodern Dönemde Türkiye'de Sosyolojik Olarak Turizm-Din İlişkisi}

\section{Öz}

Turizm, dinin postmodern dönemde görünürlük kazandığı alanlardan biridir. Bu yönüyle Türkiye özelinde turizm, dinin, kamusal/toplumsal postmodernist görünümünü yansıtması açısından önemli sosyolojik içeriklere sahiptir. Din turizmi ve İslâmî tatil konsepti bu görünürlüğün en dinamik örnekleridir. Bu nedenle turizm-din ilişkisi, din sosyolojisi açısından incelenmesi gereken önemli bir araștırma alanıdır. Arasstırma, postmodern dönemde Türkiye'de turizm ile din arasında ne tür bir iliski bulunduğunu incelemeve girismektedir. Bu bağlamda postmodern sürecte dinin ve dindarlığın turizm alanlarında ne tür değișim ve dönüșümler geçirdiği anlașılmava ve anlamlandırılmava çalıșımaktadır. Bu kapsamda çalıșmada; "din-turizm ilișkisinin postmodern boyutları nelerdir? Dinin, turizme eklemlenmesinde ne tür değisimler ortava cıkmıstır? Bu değisimler, turizmin hangi alanlarında ve ne șekilde görünürlük kazanmaktadır? Postmodern dönemde turizm, din ve 
dindarlıkları nasıl etkilemistir? Postmodern sürecte dinin turizmdeki görünümü ne sekildedir ve islevi nelerdir?" vb. problemler üzerinde durulmaktadır. Çalıșma konunun bu problematiğini sosyoloiik bir perspektifle anlamava ve anlamlandırmava girismektedir. Arastırma, turizm-din iliskisini doğrudan veva dolaylı olarak inceleven dokümanlar üzerine yapılan dolaylı gözlem yoluyla elde edilen verilerin/bulguların analizine dayanmaktadır.

Turizm-din ilişkisi Türkiye'de daha çok “din turizmi” ve “íslâmî tatil” şeklinde iki farklı görünümde belirmektedir. Her iki turizm alanında, daha çok postmodernist eğilim ve değişimler bağlamında geleneksel yaşamla farklılaşan din motifleriyle ilişkili olarak ön plana çıkmaktadır. Bu noktada gerek din turizmi gerekse İslâmîtatiller, dinin ve dindar yaşam tarzının bir kesitinde (gündelik pratiklerde) postmodern görünümü somutlaştıran önemli toplumsal göstergeler taşımaktadır. Bu postmodern görünüm dolayısıyla dindar orta kesimin gündelik yaşamında girift, paradoksal ve tüketim odaklı bir tarzın belirginleştiği yön ve muhtevalar ortaya çıkmaktadır. Bu açıdan bakıldığında söz konusu turistik alanlar, gerek turizm-din arasındaki ilişkiyi gerekse turizm-dindarlık tutum ve davranış etkileşimini ve bu çerçevede dindar kesimin postmodern tüketim pratiklerine yaklaşımını farklı yön ve boyutlarıyla resmetme imkânı sunmaktadır. Bu resimde din, dindarlık ve tüketim iç içe geçen bir kamusal/toplumsal alan ihtiva etmektedir.

Din turizmi çerçevesinde hac, umre, kutsal yerleri ziyaret vb. organizasyonlarda VìP/lüks tipinde dindar kesimleri sınıfsallaştıran/farklılaştıran ve zengin-fakir şeklinde ayrıştıran bir postmodern eğilimin dinî hayatta görünürlüğünü giderek arttırdığı gözlemlenebilmektedir. İslâmî tatil bağlamında ise, postmodern tüketim toplumuna entegre olmanın önemli bir görünümü olarak dikkat çeken beş yıldızlı (lüks) statüde, sınırsızca tüketmeyi teşvik eden her şey dahil (görece İslâmî) tatil tipinin postmodern dönemde gittikçe yaygınlaşmaya başladığı görülmektedir. Bu anlamda söz konusu turistik alanların, postmodern tüketimin belirleyiciliği çerçevesinde dindar (orta) kesimi biçimlendirdiği görülebilmektedir. Ayrıca bu postmodernist turistik görünümde din, dinî değer, sembol ve kavramlar küresel kültür endüstrisinin bir parçası olarak piyasalaştırılmakta, yabancılaştırılmakta, metalaştırılmakta, meşrulaştırıcı bir işlevle araçsallaştırılmakta ve bu anlamda bir tüketim nesnesine (objesine) dönüştürülmektedir. Bu anlamda din, dinî değer, sembol ve kavramlar geleneksel yapısından koparılarak postmodernist görünümde cezbedici bir şekilde dindar kesimlerin beğenisine/istifadesine sunulmaktadır. $\mathrm{Bu}$ da İslâm'ın temel prensiplerine ve geleneksel yorum ve uygulamalarına aykırı yeni tutum/tavır, durum veya gelişmeler ortaya çıkarmaktadır. Her iki turizm alanının tüketime dayalı postmodern görünümü, İslâm'ın haram olarak nitelendirdiği israf (savurganlık) ve önerdiği dengeli (itidalli) yaşam perspektifiyle çelişmektedir. Nitekim İslâm, bireye, gündelik yaşamda aşırılıklardan kaçınmayı ve dengeli bir yaşam tarzını tavsiye etmektedir. Bu dengenin bozulması ve dünyevi olana bağlılı̆̆ın artması durumunda din ve postmodernlik arasında gerilim, çatışma ve paradoksun arttığı gözlemlenebilmektedir.

İslâmî tatil ve din turizmi alanında postmodernist tüketim eğiliminin belirleyici bir etkisi olarak Türkiye'de, din ve dindarlıkta seküler/kapitalist sisteme entegrasyonu sağlayacak bir değişimin varl-ğını kabul etmek mümkündür. Ancak bu durum, postmodern zamanlarda İslâm'ın yeni toplumsal/kamusal görünümleriyle birlikte önemini ve varlığını büyük ölçüde koruduğu ve sürdürdüğü gerçeğini değiştirmemektedir. Nitekim din, postmodern yaşam pratiklerinin/kültürünün sınırsız, doyumsuz ve sorumsuz tüketim teşvikine rağmen, sade, doğal ve kanaatkâr bir yaşama ve dünyanın faniliğine dikkat çeken en önemli faktör olarak varlığını sürdürmektedir. Bu anlamda dinin, turizm alanlarında görülen tüketim ve haz odaklı postmodernist eğilimlere ve seküler yapılanmalara karşı en güçlü sistemi içinde barındırdığı söylenebilir.

\section{Anahtar Kelimeler}

Din Sosyolojisi, Din, Turizm, Postmodern Dönem, Türkiye 


\section{Giriş}

Toplumsal bir fenomen olan din, birçok alanla ilişkili olabilmektedir. Turizm de dinin ilişkili olduğu alanlarından biri olarak dikkati çekmektedir. Nitekim dünya genelinde farklı dinlere mensup insanlar, inançları dolayısıyla kutsal kabul ettikleri yerleri ziyaret etmekte, oralara turistik seyahatler yapmaktadırlar. Bu, turizm-din ilişkisinin önemli bir örneğidir. Turizm-din ilişkisinin somut bir şekilde ortaya çıktığı bir diğer durum, İslâm dini örneğinde dinî konsept tatillerdir. Postmodern dönemde ortaya çıkan ve son dönemde giderek yaygınlaşmaya başlayan bu tatil türünü düzenleyenler, İslâmî öğreti ve ilkeler çerçevesinde tatil faaliyeti yürüttüklerini ifade etmektedirler. Gerek din turizmi gerekse İslâmî tatil bağlamında dinin temel bir etken faktör olduğu söylenebilir. Her iki durumda da din, dinî tutum ve davranışlar, turizm veya tatil algısını şekillendirdiği gibi turizmdeki değişim ve gelişmelerde de etkili olabilmektedir. Turizm-din ilişkisine bu yönüyle bakıldığında dinin, özellikle postmodern dönemin turizm tercihinde etkili bir olgu olduğunu söylemek mümkündür. Her ne kadar din turizmi ve İslâmî tatil bağlamında din veya dindarlığın kamusal/toplumsal görünümü artmış gibi gözükse de farklı form ve şekillerde dönüşümler yaşandığı görülebilmektedir. Postmodernist eğilimlerin etkisiyle dindar kesimlerin, değişerek/dönüşerek turizm/tatil faaliyetlerine eklemlendiği ve bu durumun, çelişki, gerilim ve tartışmaların ortaya çıkmasına neden olduğu söylenebilir.

Söz konusu turizm-din ilişkisine dair durum, 1980'lerdeki bazı gelişmelerle yakından ilgili gözükmektedir. 1980'lerle birlikte Türkiye'de önemli toplumsal değişimler yaşanmıştır. Bu dönemde muhafazakâr/dindar çevrelerin ekonomik olarak önemli bir gelişim kaydettiği görülmektedir. Yeşil (Anadolu) sermayesi olarak adlandırılan muhafazakâr ticari sınıf ve bu sınıfın öncülüğünde gelişen ve güçlenen bir toplumsal yapı ortaya çıkmıştır. Bu yapı, ticaret, turizm, kültür ve sosyal birçok alanda etkili olmaya başlamıştır. Söz konusu oluşum, 1990'larda MÜsİAD (Müstakil Sanayici ve İş Adamları Derneği) gibi sivil toplum kuruluşları kurarak örgütsel bir yapıya dönüşmüştür. Bu gelişimin/değişimin, gıda, giyim, gayr-1-menkul, bankacılık, teknoloji, bilişim, sağlık, turizm vb. birçok sektöre yansımaları olmuştur. Helal gıda, helal ürün, helal konseptli hastane veya sağlık kuruluşu, helal kozmetik, helal pazar, helal otel/turizm/tatil, İslâmî gayr-1-menkul, İslâmî katılım bankacilık vb. yapılanmalar postmodern toplumsal/kamusal yaşama entegre olmuşlardır. Esasen bu yapılanma, toplumsal anlamda farklı konfigürasyonlar ortaya çıkarmıştır. Söz konusu oluşum, bir yandan dindar muhafazakâr kesimlere toplumsal olarak sağliklı, huzurlu ve güvenli yaşam alanları sunduğunu savunurken, diğer taraftan helal/İslâmî olan/olmayan şeklinde ve farklı postmodernist eğilimlerle birlikte toplumsal ayrışma ve farklılaşmalara yol açmıştır. İslâmî sermaye olarak nitelendirilen postmodern dönemde özellikle 2002 ve sonrasında din turizmi çerçevesinde hac, umre ziyaretlerinde ve kutsal yerlere seyahatlerde VIP veya lüks tipinde yeni dinî görünümler ortaya çıkmıştır. Bu ise din-turizm ilişkisi çerçevesinde dindar bireyler arasında farklılaşmalara yol açmakta ve buna ilişkin birçok tartışmayı gündeme taşımaktadır. Diğer taraftan İslâmî sermaye çevrelerinin atılımının önemli katkısının yanı sıra "postmodernizm”1 ve küreselleşmenin de

\footnotetext{
"Postmodernizm" kavramı, estetik veya epistemolojik kopuşun ötesinde, modern üretim tarzının yeni bir şekle dönüşmesinin kültürel göstergesidir. bk. Perry Anderson, Postmodernitenin Kokenleri, çev. Sungur Savran (İstanbul: İletişim Yayınları, 2009), 81.
} 
etkisiyle değişen ve farklılaşan ihtiyaçların ve Müslüman toplumların artan eğitim ve gelir seviyesinin bir sonucu olarak hem dünyada hem de Türkiye'de İslâm dinine mensup olan² toplumsal yapı dikkate alınarak din (İslam) perspektifli yeni bir turizm konsepti vücut bulmuştur.

Araștırma, postmodern dönemde Türkive'de turizm-din ilişkisini sosyolojik bir perspektifle analiz etmeyi amaçlamaktadır. Araștırmada, postmodern dönemde Türkiye'de turizm ile din arasında ne tür bir ilișki bulunduğu, postmodern dönemde dinin veva muhafazakârlığın turizm alanlarında ne tür değișim ve dönüșümler vașadığı anlașılmaya ve anlamlandırılmava çalıșılmaktadır. Bu kapsamda çalıșmada; "turizm-din ilișkisinin veya etkileșiminin postmodern görünüm ve boyutları nelerdir? Dinin ve dolayısıyla muhafazakârların turizme eklemlenmesinde dinî perspektifte ve muhafazakârlığın tutum ve davranıslarında ne tür değișimler ortava çıkmıștır? Bu değisimler, turizmin hangi alanlarında ve ne șekilde görünürlük kazanmaktadır?" vb. problemler üzerinde durulmaktadır. Bu bağlamda araștırmada, turizm-din ilișkisinin sosyolojik boyutu üzerinde durulduktan sonra Türkive'de din turizmi ve İslâmî tatil konseptinin (gelișim ve postmodern görünüm) çerçevesi çizilmekte ve bunların muhafazakâr kesimin yaşamındaki postmodern görünümleri ortaya koyulmaktadır.

Araştırmada, dokümanlar üzerine yapılan dolaylı gözlem tekniği yoluyla elde edilen veriler/bulgular, anlayıcı bir yaklaşım ve nitel bir yöntemle sosyolojik olarak anlamland1rılmaya çalışılmaktadır. Tabi burada nitel çalışmaların özünde var olan yorumlayıcı bakış açısı da ihmal edilmemektedir. Araştırmada ilk etapta araştırmanın konusuna doğrudan veya dolaylı olarak değinen kitap, makale, sempozyum bildirisi gibi dokümanlar taranmış, ilgili kısımlar tasnif edilmiş, veriler ve bulgular sistematize edilerek sosyolojik analizlerle aktarılmaya çalışılmıştır. Araştırmanın genel anlamda geniş bir kapsama sahip olması nedeniyle çerçevesi; din turizmi ve İslâmî tatil, postmodern dönem, Türkiye ve işlevsel ve sosyolojik din yaklaşımıyla sınırlandırılmıştır.

Çalışma gerek din turizmi gerekse de İslâmî tatil bağlamında Türkiye'de dinî perspektifte ve muhafazakâr çevrenin yaşam tarzında önemli paradigma değişimlerinin yaşandığını ortaya koymaktadır. Bu değişim, turizm-din ilişkisini ele almayı, bu bağlamda ortaya çıkan gelişmeleri anlamayı ve anlamlandırmayı zorunlu kılmaktadır. Bu kapsamda turizm-din ilişkisi çerçevesinde dinî turizm ve İslâmî tatil alanlarında postmodernist eğilimlerin etkisiyle dinin; piyasalaştırılarak yabancılaştırıldı̆̆ı, metalaştırıldı̆̆ı, postmodern yaşam tarzlarına eklemlenmeye dönük meşrulaştırıcı ve araçsallaştırıcı işlevselliğine başvurulduğu görülmektedir. Bu eklemlenme dolayısıyla muhafazakâr orta kesimde, girift, paradoksal ve tüketim odaklı yaşam tarzının belirginleştiği göstergeler veya izler ortaya çıkmaktadır. Böylece çalışma, turizm-din ilişkisinin ve turizm-muhafazakârlık tutum ve

2013 yılında yapılan bir araştırmaya göre; Türkiye'de yaşayan kişilerin \%99,2'si İslâm dinine mensup olduğunu belirtmişken sadece \%0,4'ü İslâm dışındaki diğer dinlere mensup ya da herhangi bir dine mensup olmadığını ifade etmiştir. Ayrıca bu araştırmaya katılanların \%87,5’i dindar olduklarını belirtmiştir. Necdet Subaşı'nın yönetiminde hazırlanan ve Türkiye çapında din, dinî hayat, dindarlık vb. boyutlara ilişkin son derece önemli veriler sunan oldukça geniş araştırma için bk. Diyanet İşleri Başkanlığı (DỉB), Türkiye’de Dinî Hayat Araştırması (Ankara: Diyanet İşleri Başkanlı̆̆ı Yayınları, 2014). 
davranış etkileşiminin farklı yön ve boyutlarında görünürlük kazanan dinin konumunu, işlevselliğini ve Türkiye'deki muhafazakâr orta kesimin gündelik hayatında postmodern tüketim pratiklerine bakıșını resmetme imkânı sunmaktadır. Bu çerçevede çalıșmanın din sosvoloiisi alanında bir boşluğa karşılık geleceği ve ilgili literatüre katkı sağlayacağı umulmaktadır.

\section{Sosyolojik Olarak Turizm-Din İlişkisi}

Turizm ve din, önemli toplumsal boyut ve işlevlere sahiptir. Her ikisinin de kitlesel yönü, toplumsal ilişkileri/etkileri/tutum ve davranış biçimleri bulunmaktadır. Bu nedenle her ikisinin de doğrudan veya dolaylı olarak birbirleriyle ilişkili bir sosyolojisi bulunmaktadır. Ancak turizm-din ilişkisi, özellikle postmodern dönemle birlikte anlaşımaya ve anlamlandırılmaya başladığı görülmektedir. Bu tarihe kadar birbirinden bağımsız olduğu düşünülen turizm-din ilişkisi, mevcut konjonktürde doğrudan veya dolaylı olarak birbiriyle ilişkili yön ve muhtevalar taşıdığı ortaya çımıştır. Türkiye'de özellikle postmodernist etki ve yönelimin bir sonucu olarak turizme dinî eklemlenmeler dolayısıyla turizm alanlarındaki dinsel görünümde artışlar yaşanmıştır. İslâmî tatiller, bu değişimin en somut örneklerinden biridir. Bu nedenle kitlesel, dinî, sosyal, kültürel, psikolojik, ticarî, siyasi, demografik, coğrafi, tarihî vb. birçok toplumsal alanı kuşatan bir görünüm çizen turizm olgusunun din boyutunu sosyolojik bir bakış açısıyla ele almak son derece önem arz etmektedir. Bu yönüyle postmodern dönemle birlikte daha fazla görünürlük kazanan turizm-din ilişkisinin, din sosyolojisi bağlamında ele alınması önemli bir boşluğu dolduracaktır. Çünkü din sosyolojisi literatürüne bakıldığında, söz konusu ilişkiyi ele alan çalışma veya araştırmalara ihtiyaç olduğu açık bir şekilde görülebilmektedir.

Din, genel anlamda toplumsal ilişki biçimlerinden tüketim eylemleri ve satın alma tercihlerine kadar birçok boyutta önemli ve belirleyici bir faktördür. ${ }^{4}$ Diğer bir ifadeyle din, birey ve toplumunun tutum, değer ve davranışları üzerinde çok boyutlu etkisi olan kapsamlı sosyal kurumlardan biridir. ${ }^{5}$ Bu yönüyle birey veya toplumun dinî özellikleri, yaşam tarzı, tercih ve seçimleri, sosyo-kültürel ve ekonomik tavırları ve tüketim kültürü gibi birçok öğede belirebilmektedir. ${ }^{6}$ Buna ek olarak, din ve dinle ilişkili uygulamalar, insanların deneyimlediği önemli yaşama geçişlerinin çoğunda (örneğin doğumlar, evlilikler ve cenaze törenleri), insanlar için önemli olan değerlerde (örneğin doğru ve yanlı̧ın ahlaki değerleri), sosyal konularda kamuoyunu şekillendirmede (örneğin, birlikte yaşama, aile planlaması, organ bağışı vb.), tüketim için izin ve yasaklamalarda (örneğin yeme ve içme kısıtlaması) ve günlük yaşamla ilgili diğer birçok boyutta genellikle etkili ve çok

3 Muhsin Halis - Abdulmenaf Korkutata, "Helal Helal midir? Turizmde Standartlar, Uygulamalar ve Sorunlar", Van Yüzüncü Yıl Üniversitesi Sosyal Bilimler Enstitüsü Dergisi 2018/İslam Kongresi Özel Sayıs1 (2018), 197.

4 Dinin önemli, etkili ve belirleyici olduğu farklı boyutları için bk. Ejder Okumuş, Din Sosyolojisi (Ankara: Maarif Mektepleri Yayınları, 2018), 55-389 vd.

5 Safiek Mokhlis, "Revelancy and Measurement of Religiosity in Consumer Behavior Research", International Business Research 2/3 (June 2009), 75; Ahmad Rafiki - Kalsom Abdul Wahab, "Islamic Values and Principles in the Organization: A Review of Literature", Asian Social Science 10/9 (April 2014), 1.

6 Aliakbar Jafari - Ahmet Süerdem, "An Analysis of Material Consumption Culture in the Muslim Word", Marketing Theory 12/1 (March 2012), 70-73. 
önemli bir rol oynamaktadır. Örneğin tüketim davranışlarında dindarlığın etkisini ve yerini uygulamalı olarak tespit etmeye çalışan anket araştırmasında geleneksel ve modern (görece daha az etkili) toplumlarda dinin, tüketim davranışlarını belirlemede halen etkin ve zaman zaman da dönüştürücü bir rol oynadığı saptanmıştır. ${ }^{8} 2019$ yılında yapılan başka bir araştırmada dindarlık ile tüketim davranışları arasında pozitif yönde, anlamlı ve güçlü bir ilişki tespit edilmiştir. ${ }^{9}$

Din, aynı zamanda toplumsal hayatın hemen hemen her alanında önemli bir danışma aracı ve meşrulaştırma işlevi görmektedir..$^{10} \mathrm{Bu}$ kapsamda dinin ilişkili ve etkili olduğu alanlardan biri de turizmdir. Son derece etkili ve çok boyutlu bir toplumsal fenomen olan dinin, özellikle dindar kesimlerin turizm ve tatil anlayışı üzerinde belirleyici bir faktör olduğu söylenebilir. Nitekim din, salt inanç, dinî hayat veya dindarlık üzerinde değil, aynı zamanda toplumsal hayatta, tüketim davranışlarında, gündelik pratiklerde ve bireysel tercihlerde şekillendirici bir role sahiptir. Tüketici davranışları üzerine yapılan bir mülakat, İslâmî bağlılı̆̆ın tüketici davranışlarını farklı tüketim biçimlerine bağlı olarak ve diğer etkileyici faktörlerle birleşerek şekillendirdiğini göstermektedir. ${ }^{11}$ Buna benzer şekilde Mokhlis, dinin veya dinî bağlılıkların insan davranışları üzerindeki bireysel ve toplumsal etkisine dikkat çekmektedir. ${ }^{12}$ Bilindiği gibi, Türkiye'de dindar kesimlerin toplumsal hayatında din, daha fazla görünürlük kazanmaktadır. Bu çerçevede din, dinî hassasiyet taşıyan birey veya toplumların turistik tercih ve davranışlarını etkileyebilmektedir. ${ }^{13}$ Örneğin din, turistik yer tercihinde ve bu yerlerdeki turistik ürün gereksinim ve çeşitlerini belirlemede etkilidir. ${ }^{14}$ Din, bu fenomen görünümüyle birçok alanda ve turizm sektöründe etkili ve önemli bir olgudur. Dinin, özellikle dindar kesimlerin turizm davranışları üzerinde etkili olduğu, bu nedenle de postmodern dönemde dinî turizme ve İslâmî konseptli tatillere rağbetin arttığı görülebilmektedir. Bu ise, din-turizm ilişkisini ve turizme etkisini ortaya koymaktadır. Ancak turizm de dinî yaşantıyı, dinî tutum ve davranışı etkileyebilmektedir.

Turizmin Türkiye toplumunun dinî hayatına birtakım etkilerde bulunduğu gözlemlenebilmektedir. Bu bağlamda turizmin özellikle din boyutu çerçevesinde postmodernist etki ve eğilimlerle birlikte toplumun veya bireyin inanç, ahlâkî değer ve tutumları üzerinde etkisi bulunmaktadır. Nitekim daha çok postmodernist etkiyle şekillenen turizm; siyaset, ekonomi, din, dinî hayat, dindarlık, kültür, eğitim, aile, sosyal ilişki vb. birçokyönü etkilemektedir. Bunun belki de en temel nedeni, turizm olgusunun öznesinin insan

7 Mokhlis, "Revelancy and Measurement of Religiosity in Consumer Behavior Research", 75.

8 İlgili araştırma için bk. Cemile Zehra Köroğlu, "Tüketim Kültürü ve Din Olgusu Üzerine Uygulamalı Bir Araştırma", Toplum Bilimleri Dergisi 8/15 (Ocak 2014), 85-120.

9 Sümeyye Ateş, Dindarlık ve Tüketim Algıları Arasındaki İlişki (Konya: Necmettin Erbakan Üniversitesi, Sosyal Bilimler Enstitüsü, Yüksek Lisans Tezi, 2019), 135-138.

10 Ejder Okumuş, Dinin Meşrulaştırma Gücü (İstanbul: Ark Kitapları, 2005).

11 Seyidov, “Tüketicilerin Davranışlarında Şekillendirici Bir Faktör Olarak İslami Bağlllık”, 388.

12 Mokhlis, "Revelancy and Measurement of Religiosity in Consumer Behavior Research", 75-84.

13 Atilla Akbaba - Fatih Çavuşoğlu, "Helal Otel Kavramı ve Türkiye'de Helal Otel Sertifikasyonu”, Uluslararası Güncel Turizm Araştırmaları Dergisi 1/1 (Haziran 2017), 50.

14 Adi Weidenfeld - Amos Ron, "Religious Needs in the Tuourism Industry", Anatolia: International Journal of Tourism and Hospitality Research 19/2 (December 2008), 358. 
olmasıdır. ${ }^{15} \mathrm{Bu}$ anlamda turizmle doğrudan veya dolaylı olarak neredeyse her konu, toplumla/bireyle ilişkili veya toplumsal/bireysel boyut içermektedir. Nitekim turizm, kültür, ırk, kimlik, din, dil vb. birçok farklı formu/yapıyı içinde taşıma kapasitesine/imkânına sahip kitlesel bir hareket özelliği taşımaktadır. Bu nedenle turizm, ekonomik bir olgu olmanın ötesinde her şeyden önce toplumsal bir olgudur. ${ }^{16} \mathrm{Bu}$ nedenledir ki turizmin toplumsal boyutlarını ele alan bir disiplin olan turizm sosyolojisi, postmodern, küresel, endüstriyel ve teknolojik toplumla birlikte 19. yüzyılda ayrı bir bilim alanı olarak vücut bulmuştur.

\subsection{Türkiye'de Din Turizmi}

Turizm-din ilişkisi, sosyolojik olarak en belirgin görüntüsünü din turizminde vermektedir. Nitekim din turizmi, ${ }^{17}$ farklı dinlere ait kutsal yapı veya yerleri görme amacı neticesinde ortaya çıkan önemli bir alternatif turizm türüdür. ${ }^{18}$ Başka bir tanımlamada din turizmi, dinî ihtiyaçları gerçekleştirmek ve inanç çekim merkezini görmek amacıyla yapılan gezilerdir. ${ }^{19}$ Bu tanımlamalarda "dinsel ihtiyaç" faktörü öne çıkmaktadır. Nitekim din turizminin, yaratıcıya daha yakın olma, hayatı anlamlandırma, manevî huzur bulma, dinsel tatmin vb. farklı birtakım nedenleri bulunmaktadır. ${ }^{20}$ Ancak (her ne sebeple olursa olsun) kutsal yerleri ziyaret etme isteği önemli bir dinsel/manevi ihtiyacı ifade etmektedir. Nitekim din turizmine katılım sağlayan bireyler, hayatı daha anlamlı kılma noktasinda motive olabilmekte ve moral sağlayabilmektedir. Rinschede'ye göre din turizmi,

15 İnsanın sosyolojik olarak turizm olgusundaki “özne” rolü için bk. Tunca Toskay, Turizm: Turizm Olayına Genel Yaklaşım (İstanbul: Der Yayınları 1989), 107-150.

16 Muammer Tuna - Aslıhan Aykaç Yanardă̆, Turizm Sosyolojisi, ed. Muammer Tuna (Eskişehir: Anadolu Üniversitesi Yayınları, 4. Basım, 2014), 68.

17 Dinî/kutsal kent veya yerleri ziyaret, dinî toplantı ve törenlere katılmak ve dinî anıları ziyaret etmek, din turizmini etkileyen etkenler arasındadır. bk. Hayati Doğanay, Türkiye Turizm Coğrafyası (Konya: Çizgi Kitabevi, 2001), 11.

18 Orhan Mesut Sezgin, Genel Turizm (Ankara: Tutibay Yayınları, 1995), 9; Öcal Usta, Genel Turizm (İzmir: Anadolu Matbaacilik, 2001), 41.

19 Erkan Dikici - Adem Sağır, “Antalya'da İnanç Turizminin Sosyolojik Çözümlenmesi: Demre-Myra Örneği”, Karamanoğlu Mehmetbey Üniversitesi Sosyal ve Ekonomik Araştırmalar Dergisi 14/22 (Mart 2012), 36.

20 Din turizmin en önemli faktörlerinden biri olan Hac seyahatinin çeşitli nedenleri için bk. Erik Cohen, "Pilgrimage Centres: Concentric and Excentric", Annals of Tourism Research 19/1 (April 2002), 33-50; Noga Collins-Kreiner - Nurit Kliot, "Pilgrimage Tourism in the Holy Land: The behavioul Characteristics of Christian Pilgrims", GeoJournal 50 (January 2000), 55-67; Justine Digance, "Pilgrimage at Contested Sites", Annals of Tourism Research 30/1 (January 2003), 143-159; Irene Kamenidou - Rafaela Vourou, "Motivation Factors for Visiting Religious Sites: The Case of Lesvos Island", European Journal of Tourism Research 9 (January 2015), 78-91; Myra Shackley, "Management Challenges for ReligionBased Attractions", Managing Visitor Attractions: New Directions, ed. Alan Fyall vd. (Oxford: Elsevier Butterworth-Heinemann, 2003), 159-171; Valene L. Smith, "Introduction: The quest in quest", Annals of Tourism Research 19/1 (January 1992), 1-17; Luigi Tomasi, "Homo Viator: From Medieval Pilgrimage to Religious Tourism via the Journey", From Medieval Pilgrimage to Religious Tourism: The Social and Cultural Ecnomics of Piety, ed. William H. Swalos - Luigi Tomasi (Westport: ABC-CLIO, February 2002), 1-24; Amalia Triantafillidou vd., "Pilgrimages: The "Promised land" for Travel Agents?", International Journal of Contemporary Hospitality Management 22/3 (April 2010), 382-398. 
dinî önemi olan yerlere yapılan seyahatleri ifade etmekte ve tamamen ya da kısmen dinî motivasyondan kaynaklanmaktadır. ${ }^{21}$

Din turizmine etraflıca bakıldığında hiç şüphesiz ki birçok boyuta sahip olduğu görülebilir. Ancak postmodern dönemde özellikle ekonomi, sosyo-kültürel ve din boyutunun daha fazla ön plana çıtı̆̆ı söylenebilir. Dinî turizmin din boyutu, salt kutsal mekânlara indirilemeyecek kadar geniş bir alana, muhtevaya ve tarihe sahiptir. Nitekim din turizmi, turizmin en kadim şekli olarak görülmektedir. ${ }^{22}$ Dinsel anlamda motive edici seyahat veya turizm, en eski turizm türlerinden biri olmakla birlikte muhtemelen dinin kendisi kadar eskidir. ${ }^{23} \mathrm{Bu}$ nedenle din turizmi bağlamında turizm-din ilişkisi tarihinin, sosyo-kültürel ve özellikle postmodern sürece bağlı yönleri bulunmaktadır. Bu yönüyle din odaklı turizmin gelişimi alternatif turizm çeşitlerinin ortaya çıkmasıyla birlikte postmodern döneme denk gelmektedir. ${ }^{24} \mathrm{Bu}$ kapsamda turizm, postmodernizmin ve küreselleşmenin sağladığı olanaklarla yakın geçmişte önemli değişim ve dönüşümler geçirmiştir. Din turizminin ortaya çıkışı ve yaygınlaşması söz konusu değişimin bir sonucudur. Din turizminin özellikle 1980-90'lardan sonra önemli gelişmeler yaşadığ1 görülmektedir. Hatta bu alan, dünyada 1994-2006 yılları arasında yaklaşık 11 milyon civarında katılımcı arttırarak önemli bir pazar haline dönüşmüştür. ${ }^{25}$ Türkiye'de ise din turizmi faaliyetlerine yönelik geniş kapsamlı çalışmalar 1995'te başlamış, bu tarihten sonra bu çerçevede birçok tur ve sempozyum düzenlenmiştir. ${ }^{26}$ Bununla birlikte Türkiye' de toplumsal, dinî ve sosyokültürel etkileşimin önemli merkezlerinden biri olan cami, kilise ve sinagog gibi kutsal yapıların yanı sıra tarihi, dinî ve kültürel yapılar (türbe, yatır, müze, han/hamam, antik kent, tapınak vb.) restore edilerek din turizmine kazandırılmıştır. ${ }^{27}$ Bu kapsamda Vakıflar Genel Müdürlüğ̈̈'nün verilerine göre 2018'in sonu itibariyle yaklaşık 5250 adet kültür varlığının restorasyonu gerçekleştirilmiştir. ${ }^{28}$

Türkiye, din turizmi potansiyeli açısından önemli bir yere sahiptir. Nitekim Türkiye, uzak geçmişten bugüne kadar Roma, Hitit, Bizans, Selçuklu ve Osmanlı gibi farklı birçok topluluğa, dine, kültüre ve medeniyete ev sahipliği yapmış, jeopolitik ve coğrafi konumu

21 Gisbert Rinschede, "Forms of Religious Tourism", Annals of Tourism Research 19 (January 1992), 52.

22 Ngozi Nneji Iheanacho, "Nigerian Praxis of Religious Tourism and Pilgrimage Motivations in The Globalizing Word”, Ciencias da Religiao: Historia e Sociedade 13/1 (September 2015), 261.

23 Rinschede, "Forms of Religious Tourism", 53.

24 Nuray Türker vd., "Dini Mekanları Ziyaret Eden Turistlerin Seyahat Motivasyonları: Kastamonu İlinde Bir Uygulama”, Safran Kültür ve Turizm Araştırmaları Dergisi 2/1 (Nisan 2019), 112-113.

25 Kevin Wright, "Religious Tourism, a new area, a dynamic endustry", Leisure Group Travel Special Edition (November 2007), 8-16.

26 Sevil Sargın, "Yalvaç’ta İnanç Turizmi”, Furat Üniversitesi Sosyal Bilimler Dergisi 16/2 (Temmuz 2006), 5; Yelda Köksal - Kerem Karabulut, “İnanç Turizmi ve Bölgesel Kalkınmaya Etkisi Ağrı İli Örneği”, Ağrı İbrahim Çeçen Üniversitesi Sosyal Bilimler Enstitüsü Dergisi 5/1 (Nisan 2019), 89.

27 Adana Seyhan Abdülrezzak Antaki (Yeni) Camii, Amasya Merkez II. Beyazıt Camii, Ankara Altındağ Arslanhane (Ahi Şerafettin) Camii ve Kümbeti, Bursa Osmangazi Muradiye (İkinci Murat) Camii, Diyarbakır Sur Ulu Camii, Edirne Merkez Büyük Sinagog, Erzurum Yakutiye Çifte Minareli (Hatuniye) Medresesi, Iğdır Merkez Şerafettin Ejder Kervansarayı, Malatya Darende Yusuf Paşa Bedesteni, bunlardan bazılarıdır (Vakıflar Genel Müdürlüğü (VGM), “Yurt İçi Taşınmaz Vakıf Kültür Varlıklarına Örnekler” (Erişim 10 Ocak 2021).

28 VGM, "Yurt İçi Taşınmaz Vakıf Kültür Varlıklarına Örnekler”. 
dolayısıyla dinî, kültürel, sosyal ve ticarî etkileşimin önemli bir merkezi olmuştur. Türkiye'nin son derece önemli çok boyutlu tarihsel birikime sahip olması, din turizminin önemli bir üssü olmasını sağlamıştır. Türkiye'de farklı bölgelerde oldukça fazla sayıda dinsel, kültürel ve tarihi eser ve değer bulunmaktadır. Bu kapsamda İslâm dini başta olmak üzere Hiristiyan ve Yahudi semavi dinlerine ait sayısız cami, birçok kilise ve sinagogun yanı sıra farklı medeniyetlere ait (antik kent, tapınak vb.) birçok tarihi yapı dikkat çekmektedir. Ayrıca Türkiye'de din turizminin önemli ziyaret destinasyonları arasında olan çok sayıda türbe, ${ }^{29}$ yatır ve müze ${ }^{30}$ bulunmaktadır. Böylece Türkiye'nin mevcut toplumsal yapısının, daha geniş dinî ve sosyo-kültürel bir görünüme kavuştuğu söylenebilir. Bu bilgiler ş̧ığında denilebilir ki din, kültür ve uygarlık açısından tarihi arka planı oldukça zengin ve çeşitli olan Türkiye, sahip olduğu potansiyel açısından din ve kültür turizmi destinasyonunda önemli bir çekim merkezidir.

Postmodern dönemde birçok insanın kutsal sayılan yerleri ziyaret ettiği göz önünde bulundurulursa denilebilir ki din, insanları turizme yönelten en önemli sebeplerden biridir. ${ }^{31}$ Nitekim dinî yapılar, törenler, ritüeller ve festivaller daima toplumların ilgisini çekebilmiştir. İslâm dininde Mekke, Medine ve Kudüs, Hıristiyanlıkta Efes, Roma, Kudüs ve Yahudilikte de Kudüs, dünya genelinde din turizminin ana merkez üsleri konumundadır. Bu merkezler, dinlerin kutsal mekânları olması dolayısıyla birey veya toplum hayatının şekillenmesinde oldukça önemli rol oynamaktadır. Bu kapsamda kutsal sayılan mekânların, toplumsal hayata yön verme ve anlam katma noktasında önemli işlevler barındırdığı söylenebilir. Dinî turizm de dinin bu işlevsel boyutu kapsamında ortaya çıkmıştır. Ayrıca dinî turizmin ortaya çıkmasında din, bir faktör ve buna yönelik turistik davranışın ana gerekçesini oluşturmaktadır. Yani din, kutsal kabul edilen yerleri ziyaret etmede belirleyici bir fonksiyona sahiptir. Nitekim kutsal mekânlar, yaratıcıyla kurulacak manevi bağ veya iletişimde önemli rol oynamaktadır.

${ }^{29}$ Konya'da Mevlana türbesi, İstanbul'da; Aziz Mahmut Hüdâyi Efendi, Eyüp Sultan, Eyyüp el-Ensari, Sümbül Efendi, Merkez Efendi, Hz. Yuşa, Şeyh Yahya Efendi, Pertevniyal Valide Sultan, Barbaros Hayrettin Paşa, Abu Şeybe el-Hudri, Kılıç Ali Paşa, Oruç Baba, Telli Baba, Tezveren Dede, Helvacı Baba, Selami Dede, Gözcü Baba, Çifte Gelinler, Tuzcu Baba, Zuhurat Baba, Laleli Baba türbeleri, Ankara'da Hacı Bayram-1 Veli ve Siyami Sultan türbesi, Bursa'da; Osman Gazi, Çoban Bey, Orhan Gazi, Okçu Baba, Cem Sultan, Yıldırım Bayezid, I. Murat türbeleri, Eskişehir'de Şeyh Edebali, Battal Gazi ve Yunus Emre türbeleri, Sivas’ta Melik-i Acem türbesi, Bilecik’te Şeyh Edebali türbeleri, Bilecik ilinin Söğüt ilçesinde Ertuğrul Gazi türbesi, Bitlis’in Ahlat ilçesinde Abdurrahman Gazi türbesi, Tokat ili Niksar ilçesinde Melik Gazi türbesi, Türkiye'deki türbelerden bazılarıdır.

30 Konya'da Mevlana müzesi, Adana Arkeoloji müzesi, Adıyaman müzesi, Afyonkarahisar müzesi, Ağrı İshak Paşa Saray1, Amasya müzesi, Ankara'da Anadolu Medeniyetleri ve Etnografya müzesi, Antalya Etnografya müzesi, Aydın'da Afrodisias müzesi, Balıkesir'de Kuva-yı Milliye müzesi, Söğüt'te Ertuğrul Gazi müzesi, Burdur'da Doğa Tarihi müzesi, Bursa'da Türk İslam Eserleri müzesi, Çanakkale Arkeoloji müzesi, Çorum Alacahöyük müzesi, Denizli Hierapolis Arkeoloji müzesi, Eskişehir Eti Arkeoloji müzesi, Gaziantep Zeugma Mozaik müzesi, Hatay Arkeoloji müzesi, İstanbul Arkeoloji müzeleri, İzmir arkeoloji müzesi, Nevşehir Hacı Bektaş müzesi, Samsun Arkeoloji ve Etnografya müzesi, Şanlıurfa Arkeoloji ve Mozaik müzesi, Van Akdamar Anıt müzesi, Türkiye'deki belli başlı müzelerden bazılarıdır.

31 Sağbetullah Meriç - Öznur Bozkurt, “İslam Dünyasının En Büyük Tarihi-Anıt Mezarlığının (Selçuklu Mezarlığı) Kültür ve İnanç Turizmi Kapsamında Değerlendirilmesi”, Nişantaşı Üniversitesi Sosyal Bilimler Dergisi 4/1 (Haziran 2016), 119. 
Kutsal kabul edilen yerleri ziyaret etmedeki amaç, dinî/manevî ve maddi istek ve beklentilerin yanı sıra salt gezmek ve yeni yerler keşfetmek şeklinde farklılaşabilmektedir. Türbe, yatır ve mezar ziyaretlerinin arka plan perspektifinde yatan amaçlardan biri, kutsalı arama ve ondan yardım dileme arzusudur. ${ }^{32}$ Türbe ziyaretlerinin sebepleri üzerinde yapılan bir araştırma anketinde, türbelerin, "manevî maksat"33 ve "dünyevi menfaat sağlamak" 34 şeklinde temelde iki ziyaret sebebinin olduğu tespit edilmiştir. Buna ek olarak atalara/ecdada bir minnet/vefa borcu anlamında türbelerde yatan zatlara karşı bir vefa borcu ve saygı ifadesi olarak da ziyaretlerin yapıldığı söylenebilir. ${ }^{35}$ Aynı araştırmada, Bâtıl inanç veya "dinî bir yaşantı biçimi" ${ }^{36}$ şeklinde üzerinde farklı değerlendirmeler yapılan bu mekânlara ziyaretçilerin birtakım işlevler yüklediği, söz konusu mekânların uhrevi ve dünyevi yararlar umulan yerler haline geldiği belirtilmektedir. ${ }^{37}$ Türbe ziyaretinin psiko-sosyal etkileri ve nedenlerini araştıran bir başka anket araştırmasında; türbenin, inanç turizmi ve özel istek kapsamında ziyaret edildiği ve orada genel duada bulunulduğu belirtilmiştir. ${ }^{38}$ Bununla birlikte türbe ziyaretleri; içki, kumar vb. kötü alışkanlıklardan kurtulma, hastalıklardan şifa bulma, zenginleşme, çocuk sahibi olma, doğacak çocuğun kız mı oğlan mı olacağını önceden bilme, adak, dilek tutma, yağmur duası, evde kalmış kızların kısmetinin açılması, işsizlerin iş bulması, rızkın artması ve geçim sıkıntısının aşılması, ev, araba, mülk, servet vb. şeylere sahip olma, düşman şerrinden emin olma, trafik kazası ve doğal felâketlerden emin olma, kayıp eşyanın bulunması, sınavlarda başarılı olma, karı-koca arasındaki muhabbeti arttırma, dışarıya ve askere giden yakınların să̆ salim dönmesi gibi farklı nedenlerle gerçekleştirilebilmektedir. ${ }^{39}$ Türbe, yatır ve mezarlar, çaresiz kalmış insanlara inanç ve geleneğin koruyucu gücünü hatırlatmaktadır. ${ }^{40}$ Dinin, birleştirici ve bütünleştirici işlevinden hareketle söz konusu yerleri ziyaret etmek, insanları birleștirici, bütünleștirici ve sosyalleștirici bir fonksiyona sahiptir. ${ }^{41}$

32 Emre Y1lmaz, “Türbe Ziyaretlerinin Sebepleri ve Fert Üzerindeki Etkileri: Bilecik Örneği”, Akdeniz İnsani Bilimler Dergisi 6/2 (Aralik 2016), 531.

33 Manevi maksatla ziyaret edenler, sadece orada dua etmek, Allah'ın rızasını kazanabilmek, ibadet etmek, sevap kazanmak, ruhen bir rahatlama duymak, türbede metfun bulunan kişiye duyulan minnettarlık sebebiyle ona karşı bir vefa borcunu yerine getirmek, manevi bir haz ve feyiz almak amacını taşımaktadırlar (Yılmaz, "Türbe Ziyaretlerinin Sebepleri ve Fert Üzerindeki Etkileri", 550).

34 Dünyevi menfaat sağlamak için ziyarette bulunanlar ise; çeşitli istek ve dileklerde bulunma maksadıyla, direkt türbede bulunan zattan değil de esas itibariyle Allah'tan istemek suretiyle, türbede metfun bulunan zat vesile kılınarak çeşitli uygulamalar eşliğinde türbeleri ziyarete gelmektedirler (Yılmaz, “Türbe Ziyaretlerinin Sebepleri ve Fert Üzerindeki Etkileri”, 550).

35 Y1lmaz, “Türbe Ziyaretlerinin Sebepleri ve Fert Üzerindeki Etkileri”, 550-551.

36 Türbe ziyaretlerini halk dindarlığı (Volk İslâm) bağlamında da değerlendirmek mümkündür (Cengiz Kanık, “Abdurrahman Gazi Türbesi ve Psiko-Sosyal Etkileri”, Sïrt Üniversitesi Sosyal Bilimler Enstitüsü Dergisi 6/11 (Haziran 2018), 137).

37 Y1lmaz, “Türbe Ziyaretlerinin Sebepleri ve Fert Üzerindeki Etkileri”, 550.

38 Kanık, “Abdurrahman Gazi Türbesi ve Psiko-Sosyal Etkileri”, 143-146.

39 Ünver Günay, “Türk Halk Dindarlığının Önemli Çekim Merkezleri Olarak Dini Ziyaret Yerleri”, Erciyes Üniversitesi Sosyal Bilimler Enstitüsü Dergisi 1/15 (Aralık 2003), 17.

40 Şenol Göka, İnsan ve Mekân (İstanbul: Pınar Yayınları, 2001), 98.

41 Yılmaz, “Türbe Ziyaretlerinin Sebepleri ve Fert Üzerindeki Etkileri”, 550-551; Kanık, “Abdurrahman Gazi Türbesi ve Psiko-Sosyal Etkileri”, 147. 
Din turizmi, bir yandan bireysel/toplumsal önemli manevi anlamlar ihtiva etmekte, diğer taraftan toplumsal anlamda bireysel/toplumsal hareketlenmeler meydana getirmektedir. Bu anlamda dinî ve sosyo-kültürel etkileşimin (religious and socio-cultural interaction) önemli bir ayağını oluşturmaktadır. Nitekim dünyanın farklı bölgelerinden farklı din ve kültürlere sahip olan insanlar, din turizmi merkezlerinde bir iletişim/etkileşim imkânı bulmaktadır. Bu sayede gittikleri yerin dinî, toplumsal, sosyo-kültürel, ekonomik, siyasi vb. birçok yapısını ve yönünü hem görme hem de bu alanlarla bir iletişim/etkileşim imkânı elde etmektedir. Aynı zamanda bu etkileşim, turizm alanlarında çok kültürlü bir topluluk veya yapı meydana getirmektedir. Bu çerçevede din turizmi, kültürler arası etkileşim/iletişimin gelişmesinde ve dünya barışına katkı sağlaması noktasında önemli rol oynamakta; toplumsal çeşitlilik ve farklılıkların görünürlük kazanmasına ve bunlara dinsel anlayış ve hoşgörüyle bakılmasına önemli katkı sağlamaktadır. ${ }^{42}$

Din-tüketim tercihi açısından dinin öğreti, ilke ve esasları çerçevesinde bireylerin tüketim davranışları üzerinde belirleyici bir rolü olduğu söylenebilir. Bu anlamda bireyin dindarlık veya seküler anlayışı/yapısı genel anlamda yaşam biçimini ve tüketim davranışını, özelde de turizme katılımını veya katılım biçimini etkileyebilmekte, hatta şekillendirebilmektedir. Yani dinî öğreti, kural veya esaslar, hem müntesiplerinin turistik davranışının şekillenmesine hem de dinî hassasiyetle hizmet veren turizm işletmelerinin vasıflarına etkisi olabilmektedir. ${ }^{43} 2010$ yllında yerli turistlerin otel seçiminde dini hayat tarzlarının etkisini ortaya koymayı amaçlayan bir anket araştırmasına göre; katılımcı yerli turistlerin dinî emirlere dair tutumları ile otel seçimleri arasında anlamlı bir ilişki olduğu ve dinî inanışların yerli turistlerin turistik ürün seçme ve satın alma davranışları üzerinde önemli derecede etkili olduğu tespit edilmiştir. ${ }^{44} \mathrm{Bu}$ araştırma bulgularına göre din, turistik seçim ve davranışlarda önemli bir belirleyici faktördür. Ancak dinin, turistik davranış ve seçimler üzerindeki bu belirleyiciliğinin devam edip etmediği veya ne oranda belirleyici etkisi olduğuna dair daha güncel nitel ve nicel araştırma verilerine ihtiyaç bulunmaktadır.

Din turizmi bağlamında dinin belirleyiciliğinin yanında bir de "tüketim praksisi" ${ }^{45}$ ne dayalı postmodernizmin etkisi gözlemlenebilmektedir. 2000 ve sonrası dönemde dinî inanç, pratik ve değerlerde önemli ölçüde bir artış olmamasına rağmen bu süreçte umre seyahatlerinde iki kat artış olmasının en önemli sebeplerinden biri, Türkiye'nin tüketim toplumu olmasının yanı sıra muhafazakâr kesimin ekonomik durumlarında ve tüketim alışkanlıklarında ortaya çıkan değişimlerdir. ${ }^{46}$ Bu değişime bağlı olarak umre, hac vb. kutsal yerleri ziyaretlerde VIP veya lüks olarak adlandırılan ve daha varlıklı (zengin) muhafazakâr kesime yönelik sunulan organizasyonlar, muhafazakâr kesimin yaşamında tüketime dayalı postmodernist yaşam eğiliminin en somut göstergelerinden biridir. Bu da

42 Ramazan Sever, “Battalgazi (Eski Malatya) İlçesinin Kültürel Peyzajinda Tarih ve İnanç Turizmi”, International Journal of Human Sciences 13/1 (Nisan 2016), 2136.

43 Ömer Akgün Tekin - Esra Yılmaz, "İslami Turizm Konseptinde Hizmet Veren Konaklama İşletmeleri Üzerine Bir İnceleme”, Uluslararası Sosyal Araştırmalar Dergisi 9/42 (Şubat 2016), 2047.

44 Söz konusu araştırma için bk. Mehmet Yeşiltaş vd., "Otel Seçiminde Dini Hayat Tarzlarının Etkisi”, Elektronik Sosyal Bilimler Dergisi 11/39 (Kış 2012), 212.

45 “Tüketim praksisi” kavramı için bk. Jean Baudrillard, Tüketim Toplumu, çev. Hazal Deliceçaylı - Ferda Keskin (İstanbul: Ayrıntı Yayınları, 3. Basım, 2008), 27-28.

46 İsmail Demirezen, Tüketim Toplumu ve Din (İstanbul: Dem Yayınlar1, 2015), 145. 
postmodern zamanlarda din turizmi bağlamında dinin farklı form veya şekiller üzerinden dindar kesimleri farklılaştırarak ayrıştırdığı söylemlerine konu olmaktadır. Bu noktadaki söylem ve değerlendirmelere bakıldığında dinin metalaştırıldığı bir postmodernist eğilimin tartışıldığı görülmektedir. Bu noktada “inanç veya din turizmi” kavramsallaştırmas1nın İslâm medeniyetine uygun bir kavram olmadığı, ileriki zamanda kutsal mekânların serbest piyasa ekonomisinin etkisiyle daha fazla metalaşacağı, ancak kutsal alanların metalaşmasının dinin manevi boyutuna zarar verdiği ifade edilmektedir. Ayrıca dindar kesimlerin hac ve umre ziyaretlerini inanç turizmi olarak anlamlandırdığı ve bu ziyaretleri sosyal konumlarını yükseltmek amacıyla bir araç olarak kullandığı iddiaları dile getirilmektedir. ${ }^{47}$ Bu noktada varlıklı dindar bireylerin "Kabe manzaralı" oda veya devre mülk kiralama/satıl almalarının son dönemde yaygınlaşmaya başladığı ifade edilmektedir. ${ }^{48} \mathrm{Bu}$ ise, VIP/lüks hac ve umre organizasyonları üzerinden bir eleştiri konusu yapılmaktadır. ${ }^{49}$ Hac ve umre ibadetlerinin, insanları eşitleme ve kulluklarının dışındaki farklılıklarını önemsizleştirme üzerine kurulu olduğu, ancak VİP hac ve umre organizasyonların sınıf farklılığına ve üstünlüğüne vurgu yaparak tüketim toplumuyla dinî hassasiyet arasındaki bir ironiye işaret ettiği ifade edilmektedir. ${ }^{50}$ VIP hac ve umre organizasyonların, bireylere ibadet kolaylığı ve paket servisi gibi olanaklar tanısa da ibadeti özünden kopardığı ve dinî değerlerin başkalaşmasına yol açtı̆̆ı, böylece hac ve umrenin dinî bir gereklilik hedefinden çok turistik gezi amacına dönüştügü belirtilmektedir. ${ }^{51}$ Hac ve umre ibadetleri bu görünümüyle "din turizmi" statüsüne indirgenerek tüketim kültürüne entegre edilmiştir. ${ }^{52}$

Umre, hac, kutsal yerleri ziyaret vb. VIP organizasyonlar, buralara katılım sağlayan orta-üst sinıf dindar kesimlerin geleneksel olandan ziyade postmodernizme eklemlenme olarak okunabilecek dinî hayat tarzını resmetmektedir. Orta-üst sınıf dindar kesimin içinde bulunduğu bu durumun temel sebeplerinden biri, dindar çevrelerin postmodernist hayatın nimetlerinden yararlanırken eski (geleneksel/klasik) söylemlerini zihinsel bir eleştiriye tabi tutmaması olarak gösterilmektedir..$^{53}$

\subsection{Türkiye'de İslâmî Tatil Konsepti}

Turizm-din ilişkisinin somut bir şekilde ortaya çıtı̆̆ı bir diğer boyut, İslâmî tatillerdir. Denilebilir ki İslâmî tatil olgusunda temel faktör ve gerekçe dindir. Nitekim İslâmî tatil, İslâmî esas, kural ve öğretiler temelinde açıklanmaktadır. Yine aynı şekilde İslâmî çerçevede (görece) Müslüman çevrelere hizmet verildiği iddia edilmekte ve hizmetin arz-talep ilişkisi neredeyse tamamen bu perspektife dayandırılmaktadır. Ayrıca bu işletmelerde

47 Ali Baltacı, "Muhafazakâr Tüketim: Türkiye'de Muhafazakârlığın Tüketim Eksenli Dönüşüm Dinamikleri”, Harran Üniversitesi İlahiyat Fakültesi Dergisi 24/42 (Aralık 2019), 130-132.

48 Mehmet Görmez, “Diyanet İşleri Başkanı Mehmet Görmez'den Uyarı”, Beyazgündem (12 Ocak 2021).

49 Söz konusu eleştiriler için bk. Pişkin, “Tüketim Toplumu'nda Din ve Dini Değerler”, 144-149; Görmez, “Diyanet İşleri Başkanı Mehmet Görmez'den Uyarı”.

50 Demirezen, Tüketim Toplumu ve Din, 91.

51 Koç, “Tüketim Toplumunda Metalaştırılan Dini Yeniden Okuma Önerisi”, 157.

52 Esra Öztürk, Tüketim Kültüründe Müslümanların İtikadî ve Ahlâkî Problemleri (Bursa: Bursa Uludağ Üniversitesi, Sosyal Bilimler Enstitüsü, Yüksek Lisans Tezi, 2019), 56.

53 Erol Sungur, "Postmodern Tüketim ve Dindarın Seçkinlik (Elitlik) Göstergeleri”, Hitit Üniversitesi Sosyal Bilimler Enstitüsü Dergisi 10/2 (Aralık 2017), 1291. 
alınan/verilen hizmet, yani arz ve talep, dinî perspektif zemininde anlam kazanmaktadır. Nitekim turizme ilişkin hizmetlerini büyük ölçüde İslâmî öğreti ve ilkelere göre şekillendirdiği iddia edilen İslâmî turizm ${ }^{54}$ işletmelerini diğerlerinden ayırt eden en karakteristik özellik din konseptli olmasıdır. Bu anlamda İslâmî tatil, turistik profil, davranış, beklenti, eğilim, sunuş ve eğlence anlayışı bakımından diğer turizm alanlarından farklılaşmaktadır. Bu farklı nitelikleri dolayısıyla İslâmî tatil, turizm-din ilişkisinin postmodern görünümünün bir boyutunu resmetme imkânı sunmaktadır.

\subsection{1. İslâmî Tatilin Gelişimi}

İslâmî tatilin gelişimi bağlamında İslâmî tatil konseptinin nasıl ortaya çıtı̆̆̆ ve bunun ortaya çıkmasında hangi etken(ler)in rol oynadığına dair kısa ve öz bir çerçeve çizmek gerekmektedir. Postmodern dönem öncesinde Türkiye'de tatilin, genel anlamda varlıklı, şehirli, kısmen (görece) seküler (Batılı) yaşam şartlarına sahip çevrelerce daha çok benimsendiği, "dindar çevrelerin yaşamında ise olumsuz bir imaja sahip olduğu" 55 ve bu nedenle de dindar kesimlerce tatil olgusuna genel anlamda eleştirel bir tavırla yaklaşıldığ söylenebilir. ${ }^{56}$ Nitekim bu süreçte genel olarak tatil, dinî ve kültürel değerleri deforme edici (bozucu) ve yozlaştırıcı boyutuyla öne çıkartılmış ve değerlendirilmiş, bu nedenle de tatil, uzun zaman boyunca dindar çevrenin bir kısmı tarafından bir ihtiyaç olarak görülmemiştir. ${ }^{57}$ Ancak postmodern dönemle birlikte Türkiye'de dindar çevrelerin eğitim ve gelir seviyesinin artması ve değișen ve farklılaşan ihtiyaçların bir sonucu olarak postmodern dönemin şartlarına uyum sağlama imkânı sağlayabilecek içerikler barındıran yeni bir (İslâmî) turizm konsepti ortaya çıkmışıır. Nitekim ihtiyaç veya talebin belirdiği her alanda veya konuda arz-talep dengesinin kurulması adına bir mal veya hizmet arzının sunulması postmodern dönemin kapitalist ekonomik anlayışının bir gereğidir. ${ }^{58}$ Böylece tatil, (görece) İslâmî argümanların ve düzenlemelerin görünür hale geldiği bir turizm pazarı olarak Müslüman tüketicilere "steril bir alan" iddiaslyla arz edilmiştir. ${ }^{59}$

Postmodern dönemle birlikte ortaya çıan İslâmî konseptli turizmin toplumsal alanında sosyolojik olarak önemli değişim ve dönüşümler ortaya çıkmışıı. Denilebilir ki bu süreçle birlikte artık turizm, (görece) salt zengin ve seçkin çevrelerin değil, aynı zamanda kendine özgü bir takım dinî konseptlerle birlikte (görece) varlıklı veya orta sınıf sivil toplumun ve bu yapıdaki dindar çevrelerin ${ }^{60}$ bir kısmının eklemlendiği bir yaşam alanı haline

54 Kadir H. Din, "Islam and Tourism: Patterns, Issues, and Options”, Annals of Tourism Research 16/4 (1989), 552.

55 Baltacı, "Muhafazakâr Tüketim: Türkiye’de Muhafazakârlığın Tüketim Eksenli Dönüşüm Dinamikleri”, 128.

56 Levent Yılmaz - Mehmet Emre Güler, “Türkiye'de Muhafazakâr Değerler Bağlamında Turizm ve Tatil Algısındaki Değişme”, Uluslararası Güncel Turizm Araştırmaları Dergisi 1/1 (Haziran 2017), 18.

57 Yılmaz - Güler, “Türkiye'de Muhafazakâr Değerler Bağlamında Turizm ve Tatil Algısındaki Değişme”, 18.

58 Baltacı, “Muhafazakâr Tüketim: Türkiye’de Muhafazakârlığın Tüketim Eksenli Dönüşüm Dinamikleri”, 129.

59 Hasan Hüseyin Aygül - Özgür Öztürk, “Dini Çoğulculuk ve Kamusal Alanda Dindar Tüketim Kültürü”, Moment Dergisi 3/1 (Haziran 2016), 199-203.

60 İslâmî otellerde tatil yapanlara öncülük edenler “İslamcı sosyete” olarak nitelendirilmektedir. bk. Vejdi Bilgin, “Popüler Kültür ve Din: Dindarlığın Değişen Yüzü”, Uludağ Üniversitesi İlahiyat Fakültesi Dergisi 12/1 (Ocak 2003), 205. 
dönüşmeye başlamıştır. Konuya Mardin'in ${ }^{61}$ "merkez-çevre" ka kavramları çerçevesinde bakacak olursak denilebilir ki, postmodern öncesi dönemde genel anlamda turizm, özel anlamda da tatil olgusu, gelir düzeyi yüksek, seçkin ve (görece) daha çok seküler hayat tarzına sahip kişilerle (merkezle) özdeşleşmişken, postmodern dönemle birlikte artık ekonomik olarak orta düzey sivil toplumu ve dindar çevreyi de kapsayacak bir alan haline dönüşmüştür. Bilici'ye göre de İslâmî tatil konseptler, kamusal/toplumsal olarak bir merkez-çevre gerilim alanını ifade etmektedir. ${ }^{63}$

Postmodern dönemde toplumların dinsel tutum veya davranışları, (tüketim eğilimine bağlı olarak) turizm alanında önemli değişimler yaşanmasında etkili olmuş ve olmaya da devam etmektedir. Buna bağlı olarak dindar çevrelerin tutum, davranış, tüketim tercih ve alışkanlığı turizmde önemli bir değişime yol açmıştır. Artık İslâmî/helal/muhafazakâr/tesettürlü tatil, tatil köyü, deniz, havuz, otel, vb. kavramsallaştırmalar, Türkiye toplumunun ve dindar kesimlerin terminolojisine girmiştir. Böylece tatil sektörü, dinî motiflerin eklemlenmesi suretiyle toplumsal meşruiyet zemini genişlemiş gözükmektedir. Turizm terminolojisinde dinî kavramsallaştırmalara gidilmesi ve turizm hizmetinin dinî hassasiyet çerçevesinde sunulmaya çalışılması ve pazarlanması, dinî açıdan turizmde önemli değişimler olduğunu göstermektedir. Dinî açıdan ortaya koyduğu yaklaşım ve gerçekleştirdiği konsept değişimiyle birlikte turizm, böylece dindar çevrelerin de ilgi alanına hitap etme imkânına kavuşmuştur. Dindar çevreler, dinlenme, rahatlama, eğlenme, yeni yerler keşfetme vb. amaçlarla turizme katılma veya tatile gitme ihtiyacı duymuşlardır. Ancak dindar çevrelerin bir kısmı bu ihtiyacı zamanla bir temel gereklilik gibi algılamaya başlamıştır. Öyle ki, mevut konjonktürde, genel anlamda orta ve üst sınıf dindar kesimlerin bir kısmında İslâmî tatil, hayatın önemli bir ihtiyacı, hatta vazgeçilmez bir parçası olarak algılandığı görülebilmektedir. Daha önce İslâm'ın akrabalık bağlarının güçlü tutulması, akrabaların ziyaret edilmesi, gözetilmesi vb. sıla-i rahim emrini gerçekleştirmek için geleneksel olarak tatillerini memlekete gitmek suretiyle gidermeye çalışan dindar kesimin tatil perspektifi değişime uğramış ve postmodern süreçte artık, memleket veya akraba ziyaretleri yerine otel tatillerini veya tatil köylerini tercih edenlerin sayısında artışlar yaşanmıştır. Dindar kesimlerin gündelik hayat perspektifinde meydana gelen bu değişim, onların hayata bakışının ve tüketim toplumuna uyum sağlama çabasının bir sonucu olmakta ve geleneksel boş zaman değerlendirme biçimlerinin farklılaşmasını göstermektedir. ${ }^{64}$ Böylece din ve boş zaman arasında kurulan dengede, esnek ve bireysel gereksinimlere dönük isteğin dinamik tutulduğu anlaşılmaktadır. ${ }^{65}$

${ }^{61}$ bk. Şerif Mardin, Türkiye'de Toplum ve Siyaset, der. Mümtaz'er Türköne - Tuncay Önder (İstanbul: İletişim Yayınları, 1990).

62 Bu kavramsallaştırmada merkezden; varlıklı ve seçkin kişiler, çevreden ise orta halli ve sivil toplum kastedilmektedir.

${ }^{63}$ Mücahit Bilici, “İslam'ın Bronzlaşan Yüzü: Caprice Hotel Örnek Olayı”, İslam’in Yeni Kamusal Yüzleri, ed. Nilüfer Göle (istanbul: Metis Yayınları, 2000), 235.

64 Baltacı, "Muhafazakâr Tüketim: Türkiye'de Muhafazakârlı̆̆ın Tüketim Eksenli Dönüşüm Dinamikleri", 129; Ejder Okumuş, Zamanin Toplumsal Gerçekliği (İstanbul: Ark Kitapları, 2011).

65 Didem Gazneli - Nilgün Sofuoğlu Kilıç, "Din Eksenli Tüketimin Yeni Medyadaki Görünümleri:Tüketim Kültürü Bağlamında Bir Değerlendirme”, Medya ve Din Araștrmaları Dergisi 3/2 (Aralık 2020), 206. 
Bu noktada Okumuş'un kavramsallaştırdığı anlamda İslâmî bir "boş zaman fikhı"ndan" bahsedilebilir.

İslâmî turizm alanında ortaya çıkan postmodernist görünüm, 2002 ve sonrası dönemin Türkiye'deki siyasal değişimin bir yansıması olarak da okunabilir. Nitekim bir toplumsal alanda ortaya çıkan değişim, diğer toplumsal alan(lar)1 etkileyebilmektedir. Öyle ki bu değişim Türkiye'nin toplumsal alanları içinde son derece önemli ve etkili bir alan olan siyasette gerçekleşmişse, diğer toplumsal alanların bundan etkilenmemesi zor gibi görünmektedir. 2002 ve sonrasında siyasal anlamda ortaya çıkan siyasî ve toplumsal değişimin koduna bağlı olarak turizm alanlarında da önemli farklılaşma, çeşitlenme ve değişimler gerçekleşmiştir. ${ }^{67} \mathrm{Bu}$ kapsamda bu süreçte genel anlamda turizmde özelde de tatil sektöründe dinî kavramsallaştırmalardan helal gıda ve malzemelerine kadar birçok din (İslâm) perspektifli yapılanmanın ortaya çıktı̆̆ı görülmektedir. ${ }^{8}$ Örneğin; "helal" veya "İslâmî" ad altında konaklama (otel veya tatil), gıda, giyim, kozmetik, finans sektörü, lojistik gibi geniş hizmet alanlarını kapsayan bir piyasa gözlemlenmektedir. Bu sektörler, çeşitli tüketim ürünleri ve kalıplarını "helal" ya da "İslâmî" olarak etiketleyerek piyasaya sürmektedir. ${ }^{69}$ Böylece İslâmî tüketici kültürü, bir kimlik oluşumu yaratarak postmodern Müslüman imajının üretimini sağlamaktadır. ${ }^{70}$ Artık yeni tüketici kimlikte muhafazakâr tüketiciler, ahlâkî prensiplerden daha çok estetik ve imaj çıkarları tarafından yönlendirilmektedir. Yeni kimlikle muhafazakâr bireylere tüketim endeksli gündelik bir yaşam sunulmakta ve böylece din veya dinî değerler "tüketilebilir bir meta" haline dönüşmektedir. ${ }^{11} \mathrm{Bu}$ rada dinin tüketilmesinden kastedilen şey, dinin bütünüyle ortadan kalkması, etkisini ve görünümünü tamamen kaybetmesi değil, tüketim kültürünün belirleyiciliği karşısında dinin veya dinî değerlerin aşındırılması ve bireylerin inanç dünyasında değer kaybına uğramasıdır. ${ }^{72}$ Nitekim tüketim arttıkça yapay ihtiyaçlar yaratılmakta, İslâmî değerler ikame değeri kazanmakta ve metalaşabilmektedir. ${ }^{73}$

66 Ejder Okumuş, Boş Zamanlar Kitabı (İstanbul: Akis Kitap, 2013), 161-162.

$67 \mathrm{Helal} /$ muhafazakâr tatil konseptleri genel anlamda önceki döneme göre şu farklılıkları barındırmaktadır: Kadın-erkek ayrı havuz, spa ve plajlar bulunması, havuz ve denizde haşema ve diz altı şort gibi kıyafet zorunluluğu bulunması, otellerde ezanın duyurulması ve otel içinde mescit olması Cuma vb. namazların cemaatle kılınması, tüketilen tüm gıdaların helal gıda sertifikasyonuna tabi tutulması, yaşam alanlarında (görece) uygun olmayan kıyafetler için uyarılarda bulunulması, odalarda seccade ve kıble işaretinin bulunması vb. değişimler gözlemlenmektedir.

68 Helal/İslâmî/muhafazakâr/tesettür otel kavramsallaştırmaları, otellerde kullanılan veya tüketilen ürün ve g1daların helal sertifikasyonuna sahip olması, İslâmî turizme bağlı olarak muhafazakâr deniz veya havuz tesettür giyimlerin piyasalaştırılması vb. yapılanmalar örnek olarak gösterilebilir.

69 İlgar Seyidov, “Tüketicilerin Davranışlarında Şekillendirici Bir Faktör Olarak İslami Bağlılık”, Selçuk İletişim 9/1 (Ağustos 2015), 391-392.

70 Nabil Echchaibi, "Mecca Cola and Burqinis: Muslim Consumption and Religious İdentities", Religion, Media and Culture: A Reader, ed. Lynch Gordon - Jolyon Michell (New York: Routledge, 2011), 2.

71 Baltacı, "Muhafazakâr Tüketim: Türkiye'de Muhafazakârlığın Tüketim Eksenli Dönüşüm Dinamikleri”, 118.

72 İhsan Çapcıoğlu, "Küreselleşme, Kültür ve Din”, Ankara Üniversitesi İlahiyat Fakültesi Dergisi 49/2 (Ağustos 2008), 171.

73 Mücahit Pişkin, “Tüketim Toplumu’nda Din ve Dini Değerler: Lüks Hac ve Umre Örnek Olayı”, İnsan ve Toplum 6/2 (Aralik 2016), 139-141. 
İslâmî tatilin gelişimi, postmodern dönemde genel olarak toplumun özel olarak muhafazakâr kesimin gündelik yaşamında etkili ve dönüştürücü bir işlev gören tüketim eğilimiyle ilişkili olduğu görülebilmektedir. Nitekim İslâmî tatil, postmodern dönemin tüketim toplumuyla entegrasyonun bir parçası olarak gelişim göstermektedir. Bu çerçevede İslâmî tatil, postmodernist tüketimin belirleyici özellikleriyle ortaya çıtı̆̆ı bir görünüm sunmaktadır. Söz konusu otellerin genel olarak müşterilerine lüks (beş yıldızlı) statüde her şey dahil (her zaman her şey sınırsızca tüketilebilir) konseptiyle hizmet sunduğu göz önünde bulundurulduğunda bir anlamda postmodern tüketim anlayışın şekillendirdiği bir tatil formu ortaya çıkmaktadır. Tüketimin belirleyici bir konumda olduğu bu postmodernist form, salt dinin veya dinî değerlerin değil, aynı zamanda olabildiğince "her şeyi" tüket mantığı çerçevesinde her türlü değer, sembol ve kavramın tüketimine dayanmaktadır. Tüketim odaklı bu postmodern anlayışta toplum için önerilen sorunsuz ve makul (ideal) birey, her geçen güç ihtiyaçları artan ve buna bağlı olarak olabildiğince, sınırsızca ve bencilce daha fazlasını tüketendir. Böylelikle artık bireyin hayatında ihtiyaca denk düşen bir nesnenin tüketilmesinden ziyade bizzat tüketimin kendisi bir ihtiyaç haline dönüşmekte; bu durumda tüketilen şey bireye bir ihtiyaç hissi yaratmaktan çok ona yüklenen anlamla ilişkilendirilerek tüketime sunulduğu için, birey onu ihtiyacı olmasa da satın alabilmekte ve onunla kimlik kazanabilmektedir. ${ }^{74}$ Her istediğini tüketme imkânı sağlayan imaj ve gösterişe dayalı bu tüketim eğilimi bireyin zihninde, "tüket ve mutlu ol” ve "tükettikçe varsın, farklısın ve fark edilebilirsin" algısını oluşturmaktadır. Bu perspektifte insanın kendini tüketerek fark ettiği, tükettikleri üzerinden kendini ifade edebildiği ve tükettikleriyle başkalarının gözünde değer kazandığı algısı bulunmaktadır. ${ }^{75}$ Hiç şüphesiz bu perspektif, "gösterişçi tüketim (conspicuous consumption)"76, "gösteri toplumu (society of the spectacle)"77, "gösterişçi dindarlık (hypocritical religiosity)"78, "dinî yabanc1laşma (religious alienation)"79 "çağdaş yabancılaşma (contemporary alienation)" 80 vb. kavramsallaştırmaların arka planında yatan algıyı göstermesi açısından önemlidir. Diğer taraftan bu perspektif, gündelik yaşamda toplumsal dayanışmayı sağlayamadığı gibi kişiselleşmeyi ve yalnızlaşmayı da belirginleştirmektedir. ${ }^{81} \mathrm{Bu}$ da toplumsal anlamda çözülmeyi beraberinde getirmektedir.

Orta ve üst sınıf dindar çevrelerin dinlenme ve tatil ihtiyacını karşılamaya dönük bir toplumsal alan sunma girişimi ve bu yönüyle postmodernizme eklemlenmenin bir biçimi

74 Olkan Senemoğlu, “Tüketim, Tüketim Toplumu ve Tüketim Kültürü: Karşılaştırmalı Bir Analiz”, İnsan ve İnsan 4/12 (Nisan 2017), 83.

75 Pişkin, “Tüketim Toplumu'nda Din ve Dini Değerler”, 139.

76 “Gösterişçi tüketim” için bk. Thorstein Veblen, Aylak Sinıf, çev. İnci User (İstanbul: Marmara Üniversitesi Teknik Eğitim Fakültesi Matbaası, 1995), 50.

77 "Gösteri toplumu" kavramı için bk. Guy Debord, Gösteri Toplumu ve Yorumlar, çev. Ayşen Ekmekçi - Okşan Taşkent (İstanbul: Ayrıntı Yayınları, 1996).

78 Gösterişçi Dindarlık algıları için bk. Ejder Okumuş, Gösterişçi Dindarlı (İstanbul: Ark Kitapları, 2. Basım, 2005).

79 Dinî yabancılaşma algıları için bk. Bekir Koç, “Tüketim Toplumunda Metalaştırılan Dini Yeniden Okuma Önerisi: Bireyin Dine Yabancılaşması Üzerine Bir Giriş”, Bingöl Üniversitesi İlahiyat Fakültesi Dergisi 1/13 (Haziran 2019).

80 Baudrillard, Tüketim Toplumu, 243-252.

81 Baudrillard, Tüketim Toplumu, 101-103. 
olarak değerlendirilebilecek İslâmî tatil, söz konusu perspektifle postmodern dönemde ortaya çıkan yeni bir turizm konsept türü olarak ${ }^{82}$ özellikle 1990'lı yıllardan sonra genel anlamda çeşitli Müslüman coğrafyalarda özel anlamda Türkiye'de önemli bir atılım gerçekleştirmiş̧tir. Türkiye'de 2002 yll itibariyle İslâmî konseptte hizmet veren işletme sayıs1 5 iken, 2015 yll itibariyle bu sayı 207'ye yükselmiştir. ${ }^{83}$ Bu da Türkiye'de İslâmî tatil konseptinde giderek artan bir ihtiyaç ve talep eğiliminin bir göstergesidir. Bu talep ise, 2002 sonrası muhafazakâr çevrelerin ekonomik refah ve sosyal statü göstergesi olarak lüks (postmodern) tüketim eğiliminin artmasının bir sonucudur. ${ }^{84}$ İlâmî otel, muhafazakâr orta sınıfın billurlaşmasında filtre fonksiyonu görerek statü yaratmaya olanak tanıyan yeni bir kamusal mekân olarak İslâmî kimliğin Türkiye toplumundaki dönüşüm rotasına dönük göstergeler sunmaktadır. ${ }^{85} \mathrm{Bu}$ anlamda İslâmî otel, İslâmî çevrenin tüketim talep ve pratiklerinin görünürlük ve bir anlamda kamusallık kazandığı bir eşik olarak görülmektedir. ${ }^{86}$

\subsection{2. İslâmî Tatilin Postmodern Görünümü}

Postmodern dönemde genel anlamda turizmde, özel anlamda tatil sektöründe dindar kesimin görünür hale gelmesi, bu alanlara ilişkin önemli değişim ve dönüşümlerin ortaya çıkmasında etken bir faktör olmuştur. İslâmî konseptli turizm veya tatil, bu temel faktör (özne) çerçevesinde yeni turistik dinî toplumsal/kamusal alanların ortaya çımasını sağlamıştır. İslâmî tatil konseptinin yaygınlaşmasıyla birlikte, dindar çevrelerin arztalep ve ihtiyaçlarına dönük olarak turizmde önemli farklılaşma ve çeşitlenmeler ortaya çıkmıştır. Bu farklılaşma ve çeşitlenmeler, önceki dönemin turistik anlayış, uygulama ve politikalarına ek olarak, Türk toplumunun dinî yapısını dikkate alan orta seviyede ekonomik şartlara haiz dindar bireylerin de görünürlüğünü yansitan bir karakteristik turizm (tatil) perspektifinin gelişimini sağlamıştır. Bu da dinî tutum, davranış ve gerekliliğin turizme olan etkisini ortaya koymaktadır. Nitekim Türkiye'deki toplumsal dinî hayatın postmodernist ve küresel yapılanmanın bir sonucu olarak turizm alanları, farklılaşarak değişime uğramıştır. Türkiye toplumsal hayatının özellikle dindar çevreler açısından turizm sahasında yeni bir düzenlemeyle ortaya çıkan bu yapılanmanın en görünen resmi ise, İslâmî tatillerdir.

Postmodern dönemle birlikte ortaya çlkmaya başlayan İslâmî turizm biçimi; "helal tatil/otel", "muhafazakâr tatil/otel", "alkolsüz tatil/otel", "tesettürlü tatil/otel", "İslâmî tatil/otel", "ailelere özel tatil/otel", "alternatif tatil/otel", "Müslüman dostu turizm" ${ }^{87} \mathrm{vb}$. farklı isimlendirmelerle ifade edilmektedir. Bundan sonra turizm sektöründe İslâmî olan-

82 Aydın'ın Didim ilçesinde Caprice Otel, Antalya'nın Alanya ilçesinde Wome Deluxe Hotel, Bera Hotel, Adin Beach Hotel, Adenya Resort Hotel, Modern Saraylar Hotel, Antalya'nın Kumluca ilçesinde Şah inn Paradise Tatil Köyü, Yalova'da Rizom Tatil Köyü ve İhlas Armutlu Tatil Köyü bunlardan bazılarıdır.

83 Akbaba-Çavuşoğlu, "Helal Otel Kavramı", 50.

84 Baltacı, “Muhafazakâr Tüketim: Türkiye'de Muhafazakârlı̆ın Tüketim Eksenli Dönüşüm Dinamikleri”, 122.

85 Bilici, “İslam’’n Bronzlaşan Yüzü: Caprice Hotel Örnek Olayı”, 236.

86 Bilici, “íslam'ın Bronzlaşan Yüzü: Caprice Hotel Örnek Olayı”, 221.

87 "Müslüman dostu turizm" kavramı için bk. Hatem El-Gohary, "Halal Tourism, Is It Really Halal", Tourism Management Perspectives 19/B (July 2016), 127. 
olmayan, helal olan-olmayan, muhafazakâr olan-olmayan otel, tatil, tatil köyü, kaplıca/termal vb. kavramlar kullanılmaya başlanmıştır. Söz konusu turistik alanlara “İslâmı̂” isim verilerek postmodern turistik alanlara eklemlenme imkânı tanınmıştır. Bu noktada İslâmî olan/olmayan turistik tatil veya etkinliklere katılan bireyler için iki farklı turistik tip kavramsallaştırmasından bahsedilebilir. Bu noktada kategorik olarak İslâmî turizm ve seküler turizm, İslâmî turist ${ }^{88}$ ve seküler turist şeklinde bir sınıflandırma yap1labilir. Nitekim Blackwell, dinî turizm bağlamında kutsal yerleri ziyaret edenleri, dinî turist ve seküler turist şeklinde kategorize etmiştir. ${ }^{89}$ İslâmî tatilin seküler-dindar sınıflandırması, bu tatillere giden kişilerden ziyade İslâmî tatil özelindeki yapısal değişim ve ayrıştırma temelinde dışardan bakıldığında ortaya çıkabilecek görünümün bir yansıması olarak ifade edilebilir. Ancak bu sınıflandırmanın, Türkiye toplumunda ayrıştırmayı daha fazla belirginleştirebileceği ve İslâmî tatillere seküler kesimin de katılabilmesi gerekçesiyle eleştirileceği muhtemeldir. İslâmî turizm/tatil yapısının Türkiye'de toplumunu turistik açıdan farklılaştırmada ve ayrıştırmada işlevsel bir rol üstendiği anlaşılmaktadır.

İslâmî turizm sektörü, dinî hayatın postmodernist turistik yapıda şekillenmesine ve turizme bağlı yeni dindarlık tipinin ortaya çıkmasına yol açmıştır. Turizm/tatil alanlarında değişerek postmodernist bir görünüm kazanan dindar kesimler, böylece küresel ve kapitalist sisteme ve tüketim toplumuna entegre olmada mesafe almıştır. Ancak bu turistik entegrasyona İslâmî değer, kavram, sembol ve motifleri taşımayı da ihmal etmedikleri görülmektedir. Nitekim tatil/turizm sektöründe dinî görünümü arttıracak (dinî hayatı ve dindar kesimleri içine alacak) şekilde birçok yeni düzenlemenin hayata geçirildiği gözlemlenmektedir. Bu çerçevede İslâmî konseptli tatil anlayışı, konaklama, yeme-içme, aktivite ve eğlence alanları dinî görünüm çerçevesinde biçimlenmiştir. Bunlar; İslâmî konseptli konaklama (odalarda Kur'an-1 Kerim ve seccade bulundurulması, namaz için kıble işaretinin konulması, TV kanallarına yönelik dinî yayınlar, helal temizlik malzemeleri bulundurulması vb.), alkolsüz/içkisiz sosyal alanlar, erkek ve kadın ayrı yaşam, etkinlik, deniz, plaj, fitness, spa, havuz ve ibadet alanları, deniz ve havuzda (bayanlar için haşema ve erkekler için diz altı şort gibi) dinî görünümlü kıyafet standartları, tüm yiyecek ve içeceklerde helal sertifikasyonu, İslâmî figür veya sembollerin öne çıkarıldığı yetişkin ve çocuk müzik ve eğlence program veya etkinlikleri, ramazan ayına özel yemek menü ve saatleri, ramazan ayına özel program ve aktiviteler, personel seçimi ve işletme personelinin giyimi, müşteriyi karşılarken ve ağırlarken personelin kullandığı dil gibi birçok alan ve yaklaşımda beliren dinî motifler görülebilmektedir. ${ }^{90}$ Bütün bunlar, turizm-din ilişkisinde tatil bağlamında dinin toplumsal/kamusal görünürlüğü göstermesi açısından önem taş1maktadır.

88 İlgili literatürde "İslâmî turist" yerine "mütedeyyin turist” kavramsallaştırmasını kullanan araştırmalar bulunmaktadır. Ayrıntılı bilgi için bakınız; Ömer Akgün Tekin, “İslami Turizm: Dünya'daki ve Türkiye’deki Genel Durum Üzerine Bir İnceleme”, Uluslararası Sosyal Araştırmalar Dergisi 7/29 (Ocak 2014), 755.

89 Ayrıntılı bilgi için bakınız; Ruth Blackwell, "Motivations for Religious Tourism, Pilgrimage, Festivals and Events", Religious Tourism and Pilgrimage Festivals Management: An International Perspective, ed. Razaq Raj - Nigel D. Morpeth (UK-USA: CAB International, 2007), 39.

90 Tekin, “ìslami Turizm: Dünya'daki ve Türkiye'deki Genel Durum Üzerine Bir İnceleme”, 756-757. 
Dindar çevrelerin sosyalleşme, dinlenme, tatil ve yeni yerler keşfetme arzusunu karşlama iddiasıyla ortaya çıkan İslâmî turizm, postmodern dönemin önemli toplumsal alanlarından biri haline gelme yolunda ilerlemektedir. Pratiksel, biçimsel, davranışsal, araçgereçsel vb. yönden din motifli görünümüyle dikkat çeken İslâmî tatil konsepti, dindar çevrenin gereksinim duyduğu tatil hizmetini beklentiler çerçevesinde sunmaya çalıştı̆̆ iddiası dindar çevrelerin ilgisini çekmeyi hedeflemektedir. Turizmde dindar çevrelerin istek ve ihtiyaçları doğrultusunda özellikle inanç ve mahremiyete duyarlı bir sistem içerisinde hizmet sunma iddiası, dindar kesimleri postmodern turist olarak toplumsal/kamusal alana dahil etme girişimidir. Bunun yanı sıra orta ve üst sınıf dindar çevreler, gündelik hayatına eklemlenen yeni toplumsal/kamusal yaşam alanlarılla birlikte genel anlamda Türkiye'de sosyolojik olarak daha geniş bir yaşamsal ortam elde etmiş gibi gözükmektedir.

İslâmî tatiller, her ne kadar "íslâm, helal, tesettür, muhafazakâr" vb. "İslâmî" olan kavramlarla dindar kesim için meşru ve cezbedici bir turistik alan görüntüsü verse de postmodern dönemin lüks, imaj, haz ve tüketim imkân ve perspektifini barındırarak önemli bir paradoksa işaret etmektedir. Söz konusu alanlarda İslâmî ahlak sınırları içinde eğlence, başka bir (seküler) dünyaya ait bir cazibe ile yan yana sunulmakta ve dünyevi zevklerle yan yana getirilmektedir. ${ }^{91}$ Bu durum, Haenni'nin ifade ettiği şekilde, plajı günahla özdeşleştiren geleneksel İslâmî düşünceyi yok sayan "zevklerin İslâmlaştırılması" kavramıla anlamlandırılabilir. Neticede postmodern öncesi İslâm ile yan yana gelmesi düşünülemeyen olgular/kavramlar, semboller ve söylemler, birlikte (yan yana) kullanılarak kuralsız ve disiplinsiz melezliği (karışımı) ve akışkanlığı savunan ve heterotopik ${ }^{93}$ dünyalar yaratan postmodernitenin rengine bürünmektedir. ${ }^{94} \mathrm{Bu}$ da İslâm'in eklektik entelektüel kurgular içerisinde silikleşmesine yol açmaktadır. ${ }^{95}$

İslâmî tatil, muhafazakâr orta kesimin toplumsal/kamusal yaşaminda bir "modern statü” göstergesi olarak yer edinmeye başladığı gözlemlenmektedir. 1970-80'li yıllarda ekonomik anlamda kamusal ve toplumsal görünümü ve gelir seviyesi artmaya başlayan İslâmî orta sınıfların "yeni statü" göstergesi olarak İslâmî oteller, geç kalınmış da olsa bir muasır medeniyet seviyesini yakalama çabası olarak kodlanmaktadır. ${ }^{96}$ Bu kodlama, Türkiye'de çağdaş Cumhuriyet elitinin sahip olduğu ancak muhafazakâr çevrenin sahip olmadığı yeni bir alana yönelik "aradaki farkı kapatma" şeklinde nitelendirilebilecek bir perspektifi göstermektedir. ${ }^{97}$ Muhafazakâr kesimin özgürce tatil yapma söylemi, "ötekisi”

91 Uğur Kömeçoğlu, "Islamic Patterns of Consumption”, Cultural Changes in the Turkic World, ed. Filiz Kıral vd. (Würzburg: Ergon-Verlag, 2007), 67.

92 Patrick Haenni, Piyasa İslam’ı (İslam Suretinde Neoliberalizm), çev. Levent Ünsaldı (Ankara: Özgür Üniversite Kitaplı̆̆1, 2011), 84 .

93 "Heterotopia" kavramı, birlikteliği olanaksız olan çok sayıda yaşam tarzının bir mekânda bir araya gelmesi anlamında kullanılmaktadır (David Harvey, Postmodernliğin Durumu, çev. Sungur Savran (İstanbul: Metis Yayinlar1, 1999), 64.

94 Erol Sungur, “Postmodern Tüketim Kültürü ve Değişen Müslüman Kimliği”, Recep Tayyip Erdoğan Üniversitesi İlahiyat Fakültesi Dergisi 3/5 (Aralık 2014), 152-153.

95 Haenni, Piyasa İslam'i, 35.

96 Bilici, “İslam'ın Bronzlaşan Yüzü: Caprice Hotel Örnek Olayı”, 226.

97 Bilici, “İslam'ın Bronzlaşan Yüzü: Caprice Hotel Örnek Olayı”, 226. 
tarafından "gerici”, “yobaz”, “gelenekçi” vb. tanımlamalarına karşı gösterdiği direnci anlatmaktadır..$^{98}$ Öte yandan muhafazakâr çevrenin postmodern tatil piyasasına eklemlenmeleri, “öteki” ile girdikleri etkileşim dolayısıyla melez kurum ve kimler oluşturmaktadır. ${ }^{99}$ Ancak bu eklemlenme, İslâmî kimliğe bir süreklilik olanağı sağlamaktadır. ${ }^{100}$

İslâmî tatil, son dönemde İslâm'ın kazandığı kamusal/toplumsal görünürlüğün yeni biçimlerinin bir parçasıdır. İslâmî tatil vb. postmodern İslâmî şekil, eğilim veya görünümler, sadece İslâmcılığın sosyal imajını ve oluşumunu yeni formlarla dönüştürmekle kalmamakta, aynı zamanda tüketim değerleri ve yeni kültürel pratiklerine alıştıkça dindar bireyler arasında yeni bir dinamiği ve cinsiyet çatışmasını getirerek İslâmî bireyleri şekillendirmektedir. Bu da dindar bireylerde yaşam tarzları üzerinden postmodernitenin bir şekilde kendini korumasına yardımcı olan bir işlevle ortaya çıkmakta ve postmodern yaşamda görünür veya var olmanın ve postmodern yaşama entegre olmanın bir öğesi haline gelmektedir. ${ }^{101}$ Bu nedenle İslâmî tatil, tüketim ve birey yönelimli dindarlıklarla seküler dünya görüşünün sembollerinin aynı alanı rahatlıkla paylaşabildiğini göstermektedir. ${ }^{102}$ Zaten postmodern tüketim kültüründe var olabilmek imaj, gösterge ve semboller üzerinden gerçekleşmektedir. ${ }^{103}$ Son tahlilde ortaya çıkan şey, postmodern tüketimin bir işlevi olarak İslâmî öznellik, düşünce ve deneyimin imkânıdır. ${ }^{104}$

İslâmî konseptli otel/tatil işletmeleri/mekânları diğer otel/tatil konseptleriyle karşılaştırıldığında dinî görünümün yanı sıra ücret dengesizliği (ödenen ücrette farklılaşma) de göze çarpmaktadır. Önemli ve büyük imkânlar taşıdığı için giderek daha fazla yaygınlaşacağı veya gelişeceği düşünülen ${ }^{105}$ İslâmî tatil konseptinin diğerlerine göre daha yüksek ücretli olması, ${ }^{106}$ önemli ve problematik bir konu olarak ortada durmaktadır. Bunlar, müşterilerine genel fiyat ortalamasının ve diğer klasik tatillerin oldukça üstünde bir ücretlendirmeyle hizmet vermektedir. ${ }^{107}$ Bu perspektifteki tatillerin ciddi fiyat dengesizliği, bir taraftan din sömürüsü/istismarını diğer taraftan dinî araçsallaştırmayı gündeme getirmektedir. Nitekim din istismarı, dinî kavram, sembol veya değerler vasıtasıyla dinî hassasiyeti olan bireylerin niyetini kötüye kullanmak suretiyle maddi veya manevi kazançlar

98 Bilici, “İslam'ın Bronzlaşan Yüzü: Caprice Hotel Örnek Olay1”, 226-227.

99 Bilici, “İslam'ın Bronzlaşan Yüzü: Caprice Hotel Örnek Olayı”, 236.

100 Bilici, “İslam'ın Bronzlaşan Yüzü: Caprice Hotel Örnek Olayı”, 217.

101 Abdullah Özbolat, "Postmodern Dünyada Din: Yaygınlaşan Dinsellik, Yüzeyselleşen Dindarlık”, İslâmî Araştırmalar Dergisi 28/3 (Aralık 2017), 271.

102 Haenni, Piyasa İslam'l, 36.

103 Sungur, “Postmodern Tüketim Kültürü ve Değișen Müslüman Kimliği”, 161.

104 Kömeçoğlu, "Islamic Patterns of Consumption", 68.

${ }^{105}$ Mohd Rizal Razalli vd., "Developing a Moder for Islamic Hotels: Evaluating Opportunities and Challenges", International Conference on Knowledge, Cultur and Society 2012 (ICKCS 2012) (Jeju Island, South Korea: 29-30 June 2012), 94; Hasret Poyraz - Kutay Oktay, "Helâl Konseptli Otellerde Tutundurma Stratejilerine Yönelik Bir Değerlendirme”, Uluslararası Türk Dünyası Turizm Araştırmaları Dergisi 2/1 (Bahar 2017), 109.

106 Muhafazakâr tüketicilerin İslâmî turizme bakışını ele alan 2018'de yapılan bir nitel araştırmada katılımcıların İslâmî otellerin pahalı olduğu konusunda fikir birliği içerisinde olduğu belirtilmiştir (Nil Esra Dal - Gülnihal Topay, "Muhafazakâr Tüketicilerin Helâl Turizme Bakışı", Avrasya Sosyal ve Ekonomi Araştırmaları Dergisi 5/12 (Aralık 2018), 277); benzer sonuçlara ulaşan diğer bir nitel araştırma için bakınız; Yeşiltaş vd., "Otel Seçiminde Dini Hayat Tarzlarının Etkisi”, 213.

107 Poyraz - Oktay, "Helâl Konseptli Otellerde Tutundurma Stratejilerine Yönelik Bir Değerlendirme”, 104. 
sağlamak, kendi menfaati için bir nevi dini aracı kılmaktır. İslâmî otellerin bir taraftan "İslâmî”" tatil iddiası, diğer taraftan aynı (beş yıldız ve her şey dahil) statüde hizmet veren İslâmî olmayan tatillere göre yüksek ücretle hizmet vermesi, İslâm dininin yasakladığı adaletsizliğin ve israfın göz ardı edildiğini ve bu anlamda dinin bundan olumsuz etkilendiğini göstermektedir. Bu durumdan özellikle zekât, sadaka ve infak gibi paylaşımı ve dayanışmayı amaçlayan dinî emir ve tavsiyeler olumsuz etkilenebilmektedir. Diğer taraftan bu ücret dengesizliği, kapitalist küresel sistemin de bir anlamda Türkiye girdisi (formu) olarak görülebilir. Dindar kesimlere hizmeti amaçlayan tatilin diğer tatillere oranla ücretlerinin daha yüksek olması, İslâmî ilke veya prensiplere aykırı olarak zengin dindar-fakir dindar ayrımını derinleştirmektedir.

Esasen İslâmî tatil türü gelişmeler, bir anlamda postmodern sürecin dinsel ve seküler karşıtllı̆ını birlikte sürdürebilme eğiliminin bir işareti olarak durmaktadır. Nitekim söz konusu turizm alanları, Türkiye'deki İslâmî kesimleri kapitalist küresel sisteme eklemlenmenin bir göstergesi olmaktadır. Ancak bu konu, Türkiye'de farklı yaklaşım veya anlayışlar çerçevesinde tartışılmaktadır. Bu noktada farklı iki yaklaşımın öne çıktı̆̆ı görülebilmektedir. Birincisi; Türkiye'deki orta sınıf dindar kesimlerin bir kısmı İslâmî tatil olarak nitelendirilen tatil tercihini bir hak olarak değerlendirmektedir. Bu yaklaşımı savunanlar, İslâmî tatili, yeni yerler görme ve kültürel anlamda katkı sağlayıcı bir bakış açısıyla yorumlamaktadır. Ayrıca Müslümanların İslâmî tatil vb. dünya nimetlerinden uzak durmasının, Müslümanları kötü koşullarda yaşamaya mahkûm etmek ve seküler kesimlere alan açmak anlamına geldiği belirtilmektedir. ${ }^{108}$ Bu nedenle dindar kesimlerin seküler kesime karşı "her yerde varız" ve "Müslüman her şeyin en iyisine layıktır" ${ }^{109}$ düşüncesiyle örnek teşkil etmesi gerektiği ve kendi tarzını oluşturmak suretiyle tüm toplumsal alanlarda görünürlük kazanması gerektiği savunulmaktadır. Bu yaklaşım tarzı, dindarların toplumsal ve gündelik yaşam pratiklerinin kapitalizme eklemlenen bir İslâmî anlayışı göstermektedir. Bu da İslâmî tatil tercihinde bulunan dindar kesimleri kamusal/toplumsal ilişki/rekabet çerçevesinde öne çıkarırken, diğger taraftan İslâmî kesimin kendi içindeki gerilim, farklılaşma ve sınıfsal ayrışmalarını belirginleştirmektedir. ${ }^{110}$ İkinci yaklaşımda ise; İslâmî tatilin, özünde İslâm'a yabancı bir şey olduğu, modern ve kapitalist dünya sistemine eklemlenme çabasının bir ürünü olduğu ve kapitalizmi meşrulaştırmanın bir aracı olduğu, lüks ve israfı çekici kıldığı ve bu nedenle de İslâm'ın yaşam tasavvuruna ve temel ilkelerine aykırı olduğu şeklinde değerlendirmeler yapılmaktadır. ${ }^{111}$ İlk yaklaşımda İslâm ile kapitalizm arasında postmodern dönemin yaşam imkânlarını benimseyen uzlaşmacı yaşam tarzı arayışları hakimken, ikinci yaklaşımda kapitalizmin ortaya çıkarabileceği seküler yaşam stilinin İslâm'ın yaşam tasavvuru ve ilkelerine aykırı olduğu gerekçesine dayanmaktadır. Ancak her halükârda bu durum, Türkiye'deki dindar kesimin bir kısmının İslâm'ın yaşam tasavvuru ile kapitalist dünya sistemi arasında veya İslâmî yaşam ile postmodernist/seküler yaşam arasında açmaz ve çelişkilerle dolu bir sıkışmışlığı göstermektedir.

${ }^{108}$ Abdullah Özbolat, “Tüketim Bağlamında Dindarlığın Dönüşümü”, Birikimdergisi (Erişim 9 Ocak 2021).

${ }^{109}$ Kübra Küçükşen, Dindarların Para ile İmtihanı Holding Tecrübesi (Konya: Çizgi Kitabevi, 2012), 176-177.

110 Özbolat, "Tüketim Bağlamında Dindarlı̆̆ın Dönüşümü”.

111 Bilici, “íslam’ın Bronzlaşan Yüzü: Caprice Hotel Örnek Olayı”, 219-220. 
Postmodern dönemin İslâmî tatil konsepti; İslâm-turizm, İslâm-turistik davranış ve eğilimler, İslâm-kapitalizm, İslâm-tüketim, İslâm-postmodern toplumsal yaşam alanları veya imkânları, İslâm-lüks yaşam, İslâm-israf vb. karşılaştırmaları bir araya getirmek suretiyle dindar kesimleri bir tercihte bulunmaya yöneltmektedir. Bu noktada dindar kesimlerin üç farklı seçeneğe tabi tutulduğu anlaşılmaktadır. Bunlardan birincisi; dindar kesimlerin kamusal/toplumsal alanlardaki artan görünürlügünü destekleyici mahiyette yaklaşımlardır. Bu yaklaşımı savunanalar, İslâmî tatil konseptine olumlu yaklaşanlar ve bu tip turizm alanlarının yaygınlaştırılması gerektiğini düşünenlerdir. Bunlar, postmodern dönemin turistik yaşamsal şart ve imkânlarını muhafazakâr hayat tarzına eklemlemek suretiyle kamusal/toplumsal/turistik alanlarda görünür hale gelerek seküler kesimlerin alanlarını daraltma eğilimi taşımaktadır. Bu yaklaşım şekli, "kendimize özgü yaşantımızla her yerde varız ve başarılıyız" ifadesinde anlamını bulmaktadır. ${ }^{112}$ Haenni, postmodern süreçte dindar kesimlerin bu yaklaşım tarzını, Müslümanların hem manevî hem de maddi (ticari) yönden yükselme hedefine bağlamaktadır. ${ }^{113}$ Göle ise bunu, dindar kesimlerin dindarlık-kamusallık ve Müslümanlık-modernlik arasını bulma anlamında bir arayış ve anlam dönüşümü olarak ifade etmektedir. ${ }^{114}$

İkincisi; İslâmî prensiplere aykırı olan postmodernist eğilimlere ve kapitalist dünya sistemine karşı durmak için İslâmî tatil olarak ifade edilen ve seküler hayat motifleri içeren postmodern çelişkilerden kurtulmak gerektiği görüşüne dayanmaktadır. Bu yaklaşımda dindar kesimlerin, şüpheli şeylerden/alanlardan uzak durması gerektiği, zühd ve takvayı önceleyen lüks ve israfı reddeden klasik (geleneksel) İslâm hayat sınırları çizgisinde devam etmesi gerektiği değerlendirilmektedir. Bu yaklaşıma göre dindar kesimlerin postmodern "tüketim" üzerinden statü, haz ve mutluluk vadeden gündelik yanılsamalara aldanmaması gerektiği, bu anlamda İslâm dinine göre asıl kalıcı mutluluğun lüks ve israftan kaçınmakla elde edilebileceği belirtilmektedir. Bu anlamılla postmodern tüketim praksisi, tüketilmiş bir yansımadan başka bir şey değildir.

Üçüncüsü; dindar kesimlerin toplumsal/kamusal hayatında dinin aksayan yönlerinde postmodern dönemin gereklerine ve şartlarına göre karar vermek gerektiği üzerinde yoğunlaşmaktadır. Bu yaklaşımda dine bir "meta" olarak yaklaşılmakta ${ }^{115}$ ve dinin özel alana ait bir olgu olduğu, modern değerlerle dinî değerler arasında bir kopuş olduğu ve bu nedenle de dinin modernleşen gündelik hayatın dışında tutulması gerektiği belirtilmektedir. ${ }^{116}$ Bu noktada üçüncü yaklaşımda dine ve dinî hayata bakış perspektifi postmodern tüketim kültürü, statü ve hedonizm (hazcılık) bağlamında değerlendirmek daha isabetli olacaktır. Nitekim postmodern dönemde İslâmî tatil bağlamında dinî hayat şekillerinde ve postmodern eğilimler karşısında dini konumlandırma eğilimlerinde birçok faktörün yanı sıra bir anlamda etkili olan şey, daha lüks ve daha iyi yaşama haz ve talebidir.

112 Özbolat, “Tüketim Bağlamında Dindarlığın Dönüşümü”.

113 Haenni, Piyasa İslam'i, 17.

114 Nilüfer Göle, Seküler ve Dinsel: Aşınan Stnırlar, çev. Erkal Ünal (İstanbul: Metis Yayınları, 2012), 46.

115 Özbolat, "Postmodern Dünyada Din", 269.

116 Necdet Subaşı, Gündelik Hayat ve Dinsellik (İstanbul: İz Yayınları, 2004), 116. 
Haz (tatmin olma) üzerine kurulan postmodernist gündelik yaşam tasavvuru bireyi; tercih önceliğini kendisine azami tatminleri sağlayacak olan nesnelere vermeye götürmektedir. ${ }^{117} \mathrm{Bu}$ bağlamda hedonizm, tüketim kültürüyle bağlantılı olarak gündelik yaşamda artan bir görünürlük kazanmaktadır. Postmodernist (hedonistik) eğilim, insanların haz, istek ve arzularının önünü açmaya dönük imkânlar sunmakta ve böylece insanı kendisine yabancılaştırmakta ve onu imajinatif bir dünyanın içine sokmaktadır. ${ }^{118} \mathrm{Bu}$ perspektifte din, küresel kültüre eklemlenerek geçmişte özdeşleşmiş olduğu gelenekten uzaklaşmasını ve otantikliğini yitirmektedir. ${ }^{119}$ Böylece küresel kültür, her türlü değer ve inancın hızlıca tüketimini sağlayarak gittikçe artan bir sekülerleşmeyi beraberinde getirmektedir. ${ }^{120}$

İslâmî tatillerin genel anlamda her şey dahil konsepti, postmodern tüketim kültürü çerçevesinde anlamlandırılabilir. Bu tatil tipinin her şey dahil konsepti sınırsız bir şekilde "olabildiğince tüket" anlayışını göstermektedir. Ancak bu anlayış, İslâm'ın israf (savurganlık) ve dengeli (itidalli) yaşam perspektifiyle çelişmektedir. Nitekim İslâm, bireye, dünya ve ahiret için dengeli bir yaşamı (aşırlıklardan uzak bir orta yolu) tavsiye etmektedir. Bu dengenin bozulması ve dünyevi olana bağllı̆̆ın artması durumunda din ve postmodernlik arasında gerilim, çatışma ve paradoksların arttı̆̆ı gözlemlenebilmektedir. ${ }^{121}$ Nitekim otel/tatil mekânlarının dindar kesimde oluşturduğu algı ve yaklaşımı örneklem grubuyla inceleyen bir araştırmada dindar kesimlerde tatil/otel bağlamındaki yaşam biçimlerinin çelişki ve çatışmalar içerdiği ve bu zıtlıkların postmodern söylemlerle aşılmaya çalışıldığı tespit edilmiştir. ${ }^{122}$ Dindar kesimlerin hayat tarzının postmodern yaşamla şekillenmesi çerçevesinde "dinî metalaştırma ve din tüketicileri" ${ }^{23}$ kavramsallaştırması da bu perspektifle ilişkili olarak ortaya çıkmaktadır.

Bütün bu tartışma veya paradokslar, dindarların İslâmî tatil vb. ile toplumsal/kamusal alanlardaki 1980 sonrası görünürlüğünün bir yansıması ve İslâm’ın popülerleşmesi bağlamında ciddi boyutlarıyla ön plana çımaktadır. Kömeçoğlu'na göre İslâmî tatil söylemi, İslâmî ahlakın korunduğunu ileri sürmekte, ibadet saatlerine uygun düzenlemelere ve alkolsüz içeceklerin servisine vurgu yapmakta ve toplumsal alan ile özel alan arasındaki İslâmî sınırı korumayı ifade eden (huzurlu, sakin, sorunsuz tatil) "huzurlu tatil"i teşvik etmektedir. ${ }^{124}$ Böylece İslâmî tatil, tüketim toplumunun postmodern yaşam tarzlarını mütevazi dindar kimliklerin simgeleri ve sembolleriyle birleștirilmektedir. ${ }^{125}$ Dindar kimliğin tüketici yaşam tarzlarıyla entegrasyonu neticesinde ortaya çarpık kimlikler çıkarmaktadır. ${ }^{126} \mathrm{Bu}$ da

117 Baudrillard, Tüketim Toplumu, 78.

118 Mustafa Tekin, "Postmodernizmin “Din” Sorunu”, Milel ve Nihal 12/2 (Temmuz 2015), 22.

119 Çapcioğlu, “Küreselleşme, Kültür ve Din”, 171.

120 Çapcioğlu, “Küreselleşme, Kültür ve Din”, 171.

121 Özbolat, "Postmodern Dünyada Din”, 274.

122 Bakınız; Erol Sungur, Postmodern Tüketim Anlayışında Dindar Yaşam Biçimleri (Rize: Recep Tayyip Erdoğan Üniversitesi, Sosyal Bilimler Enstitüsü, Doktora Tezi, 2016).

123 Koç, “Tüketim Toplumunda Metalaştırılan Dini Yeniden Okuma Önerisi”, 154-156.

124 Kömeçoğlu, "Islamic Patterns of Consumption", 66.

125 M. Hakan Yavuz, Modernleşen Müslümanlar, çev. Ahmet Yıldız (İstanbul: Kitap Yayınevi, 2008), 138-139; Kömeçoğlu, "Islamic Patterns of Consumption", 66.

126 Öztürk, Tüketim Kültüründe Müslümanlarnn İtikadî ve Ahlâkî Problemleri, 61. 
dindarların gündelik yaşam tarzının muğlaklaşmasına (bulanıklaşmasına) neden olmaktadır. Zaten postmodernlik, genel anlamda gündelik yaşamda din, kültür ve gelenekler arasındaki ayrımın bulanıklaşmasına (belirsizleşmesine) imkân tanımaktadır. Postmodernliğin ana kavramlarından biri olan "hipergerçeklik" de gerçek olan ile olmayan arasındaki bu bulanıklığı aşmaya yönelik bir kavramsallaştırmadır. ${ }^{127}$

Üretim odaklı yaşam tasavvuru içerisinde modernitenin akıl, bilgi, teknoloji ve rasyonalite üzerine temellendirilen ve dine mesafe koyan gündelik yaşam pratiklerine karşılık postmodernite, tüketim odaklı bir yaşam tasavvuru içerisinde dinin de farklılaşarak veya “şey”leşerek (nesneleşerek) gündelik yaşamda karmaşık, paradoksal ve karşıt öğelerle yan yana bir form içerisinde görüntü vermesine işaret etmektedir. Gündelik yaşam ile din, dinî sembol ve pratikler arasındaki bu girift söylem ve yapı, postmodernizmin temel problemlerinden biri olarak en fazla eleştirilen konularından biridir. Nitekim bu perspektifte dinî sembol, kavram ve pratikler gündelik yaşantının tüketim evreni içinde birer meta haline gelmektedir. ${ }^{128}$ Postmodernlik genel anlamda hayatın tüm renklerini özel anlamda dinin farklı renklerini aynı potada ve piyasa mantığına göre biçimlendirmektedir. ${ }^{129}$

Muhafazakâr kesimin postmodern tüketimi benimsemesinin ana nedeni, farklı kamusal davranışları, eylemleri, görünümleri ve yeni sosyal form tarzlarına kadar yeni olan her şeyi denemek istemeleridir. ${ }^{130} \mathrm{Bu}$ ise, kabul edilmiş İslâmî sınırlara tepki gösterme ve bunu yeniden test etme ve uyarlama meselesidir. ${ }^{131}$ Nitekim 1980'li yıllarda İslâmcı kimlik etrafında şekillenen mazlum ve mağdur söyleminden (sınıfsal ve ideolojik ezilmişlik ve dışlanmışlik duygusu), tüketim sürecine daha yoğun bir şekilde katılan ve tüketimle barış1k bir İslâm kimliğine doğru bir dönüşümden bahsetmek mümkündür. ${ }^{132}$ Bu dönüşümde "tatil yapmak", mahremiyetle tanımlanan İslâmî kimlik ile yüzleşmenin bir unsuru olduğu postmodern yaşam tarzlarının birbirleriyle bağdaşabilir olduğuna dair geniş bir anlam formuna işaret etmektedir. ${ }^{133}$

İslâmî tatil mekânlarında İslâmî mahremiyetin yaratılması, özel ve kamusal/toplumsal alan arasındaki geleneksel ayrıma meydan okumaktadır. ${ }^{134}$ Diğer bir ifadeyle İslâmî tatil, dinî değerler açısından özel alanın kamusallaştığı/toplumsallaştığı bir yapısal dönüşümü beraberinde getirmektedir. Bu yapısal dönüşümde dindar bireylerin dinî değer ve ilkeler ile tüketim istek ve ihtiyaçları arasında çelişkili durumlar ortaya çıkmakta ve bu paradoksal durumu açıklayabilecek meşrulaştırıcı unsurlara gereksinim duyulmaktadır. Nitekim dindar bireyler, postmodern dünyada açık bir şekilde görülmek, fark edil-

\footnotetext{
127 Steven Best - Douglas Kellner, Postmodern Teori, çev. Mehmet Küçük (İstanbul: Ayrıntı Yayınları, 1998), 149.

128 Erkan Perşembe, "Modernlik ve Postmodernlikte Din Problemi”, Ondokuz Mayıs Üniversitesi İlahiyat Fakültesi Dergisi 14/ 14-15 (Haziran 2003), 176.

129 Perşembe, "Modernlik ve Postmodernlikte Din Problemi”, 178.

130 Kömeçoğlu, "Islamic Patterns of Consumption", 68.

131 Kömeçoğlu, "Islamic Patterns of Consumption”, 68.

132 Bilici, “İslam'ın Bronzlaşan Yüzü: Caprice Hotel Örnek Olayı”, 225.

133 Bilici, “İslam'ın Bronzlaşan Yüzü: Caprice Hotel Örnek Olayı”, 227.

134 Kömeçoğlu, "Islamic Patterns of Consumption”, 66.
} 
mek ve tercihleriyle var olmak eğilimi içerisinde bulunmakta ve dinî eğilimlerini postmodern toplumun popüler vasitalarıyla ilişkilendirerek dönüştürme arzusu taşımaktadır. ${ }^{135}$ Bu anlamda "islâmî tatil", postmodern dönemin tatil kültürüne dindar (özellikle orta ve üst sınıf) bireylerin eklemlenmesine imkân tanıyan bir "dinî meşrulaştırım" ve "dinî araçsallaştırma" sembolü veya unsuru olarak değerlendirilebilir. Bu bağlamda postmodernite ile sıkışık, karmaşık (girift), paradoksal, rekabetçi ve kaçamaklı ilişkiler geliştiren (tüketim odaklı) dindar yaşam tarzları, dinî meşrulaştırım ve araçsallaştırma vasıtasıyla kamusal/toplumsal alanlara yönelik görünürlüğünü ve etkisini arttırmayı (güç alanını genişletmeyi) denemektedir.

\section{Sonuç}

Türkiye özelinde sosyolojik olarak turizm-din ilişkisi, din turizmi ve İslâmî/muhafazakâr tatil konsepti olarak iki farklı görünümüyle dikkat çekmektedir. Her iki alan, daha çok postmodernist eğilim ve değişimler bağlamında geleneksel yaşamla farklılaşan din motifleriyle ilişkili olarak ön plana çıkmaktadır. Bu anlamda gerek din turizmi gerekse İslâmî tatiller, dinin ve muhafazakâr yaşam tarzının bir kesitinde (gündelik pratiklerde) postmodern görünümü somutlaştıran önemli toplumsal göstergeler (işaretler) taşımaktadır. Örneğin din turizmi çerçevesinde ViP/lüks tipinde dindar kesimleri sınıfsallaştıran/farkllaş̧ıran ve zengin-fakir şeklinde ayrıştıran organizasyonel bir postmodern yönelimin dinî hayatta görünürlüğünü giderek daha çok arttırdığı gözlemlenebilmektedir. Bu postmodernist eğilim, Türkiye toplumsal hayatında ve özellikle dindar kesim arasında ayrıştırıcı gelişmelere yol açabilecek bir potansiyel taşımaktadır. Diğer taraftan din turizmi ve İslâmî tatil perspektifinde dinin, postmodernist yönelimin etkisiyle metalaştırlması ve yabancılaştırılmasıyla ilgili tartışmaların odağı haline geldiği anlaşılmaktadır. Bu da İslâm'ın temel prensiplerine ve geleneksel yorum ve uygulamalarına aykırı yeni tutumlar/tavırlar, durumlar veya gelişmeler ortaya çıkarmaktadır.

Din turizmi ve İslâmî tatil konseptinde, dinî değer, argüman veya semboller meşrulaştırıcı bir işlev olarak araçsallaştıılarak geleneksel yapısından koparılmakta ve postmodernist görünümde cezbedici bir şekilde dindar kesimlerin beğenisine/istifadesine sunulmaktadır. Bu anlamda dinin veya dinî değerlerin postmodernizmin hizmetinde/emrinde küresel kültür endüstrisinin bir parçası olarak metalaşmasına ve yabancılaşmasına imkân tanınmaktadır. Din turizmi ve İslâmî tatil bağlamında yükselen bir trend olan hedonistik postmodernist eğilim, insanların haz, istek ve arzularının önünü açması dolayısıyla insanı kendisine yabancılaştırdığı gibi onu imajinatif bir dünyanın içine sokmaktadır. Bu da postmodernist yaşamın gereklerini önceleyen İslâmîbir yaşam tasavvurunun ikamesinde eleştiri süzgecinden geçirilmeden olabildiğince dünya nimetlerinden yararlanma ve haz duyma endeksli bir yaşamı resmetmektedir. Bu resimde din ve tüketim iç içe geçen bir kamusal/toplumsal alan ihtiva etmektedir. Tatmin olma üzerine kurulan postmodernist gündelik yaşam tasavvuru bireyi, tercih önceliğini kendisine azami tatminleri sağlayacak olan nesnelere vermeye götürmektedir.

135 Özbolat, "Postmodern Dünyada Din”, 275. 
Postmodern zamanların popüler boş vakit geçirme araçlarından biri olan İslâmî tatil ve din turizmi alanlarında ve turistik davranışlarda dinin, piyasalaştırıcı ve metalaştırıcı görünümleriyle ortaya çıtı̆̆ı söylenebilir. Bu da dinin geleneksel bağlarla olan boyutları yerine postmodern koşullarda paradoksal, gerilimli ve uzlaşmacı yönlerin birlikte var olduğu yeni görünümleri doğurmaktadır. Geleneksel yapılarda daha çok ön plana çıkan dinin kapsayıcı formları, genel anlamda, postmodernizmin bireyselleşme eğilimine cevap vermede yetersiz kaldığı düşünülmektedir. Din turizmi ve İslâmî tatil özelinde dinin, firma-müşteri arasındaki arz-talep ilişkisini sağlayıcı bir araç ve müşteriyi çekebilecek bir ticarî meta olarak görülmesiyle birlikte bir tüketim objesi/nesnesi veya "tüketilebilir" bir olgu olarak dönüşmeye başlamıştır. Burada dinin tüketilmesinden kastedilen şey, dinin bütünüyle ortadan kalkması, etkisini ve görünümünü tamamen kaybetmesi değil, tüketim kültürünün belirleyiciliği karşısında dinin veya dinî değerlerin aşındırılması ve bireylerin inanç dünyasında değer kaybına (erozyona) uğramasıdır. Postmodernist dinî yaşam biçiminde dinî esas ve ilkeler/prensipler temelli bir yaşam biçiminin oluşturulamaması, dinin ve dinin emrettiği değerlerin aşındırılmasına/örselenmesine yol açmaktadır. Buna bağlı olarak dinî pratik ve davranışların da bir değișime uğradı̆̆ı anlaşılmaktadır. Diğer bir ifadeyle dinî değer ve algıların postmodern tatil kültürüyle girdiği etkileşimin bir sonucu olarak dinî pratiklerin de dönüştürüldüğü gözlemlenebilmektedir. Bu noktada dinturizm ilişkisi çerçevesinde dinin, postmodernist eğilimlere uygun olarak bireyselleşerek metalaştığı ve yabancılaştı̆̆ı söylenebilir.

Özetle İslâmî tatiller, boş zamanın tüketilmesinde dindar bireylere metalaşmış dinî değerler ile araçsallaşmış ve yabancılaşmış bir dindarlık alanı sunmaktadır. Bu ise, postmodernizmin seküler ve kapitalist eğiliminin bir yansıması olarak dinî değer ve sembollerin yanı sıra dindarlığın da şekil ve içerik açısından dönüşümünü göstermektedir. Böylece geleneksel yapıda bulunan dinî formların bir kısmında anlamsal ve içeriksel değişimler ortaya çıkmıştır. Bu değişimde, din ile sekülarizm/kapitalizm arasında bir yandan postmodernist kesişim gerçekleşmekte, diğer taraftan bu ikisi arasında çatışma belirginleşmektedir. Kısacası İslâmî turizmde ve din turizminde postmodernist tüketim eğilimlerinin bir sonucu olarak Türkiye'de din ve dindarlıkta seküler/kapitalist sisteme entegrasyonu sağlayacak bir değişimin varlığını kabul etmek mümkündür. Bu noktada Haenni'nin Piyasa İslam'ı adlı eserinde savunduğu; kapitalist modernleşme ve küreselleşmenin etkisiyle hemen her şeyin "piyasa mantığı” çerçevesinde değerlendirildiği konjonktürün İslâm’ı başkalaştırdığı temel iddiası, bir anlamda Türkiye özelinde bir gerçeklik ifade edebilir. Ancak bu durum, postmodern zamanlarda İslâm'ın, yeni toplumsal/kamusal görünümleriyle birlikte önemini ve varlığını büyük ölçüde koruduğu ve sürdürdüğü gerçeğini değiştirmemektedir. Nitekim din, postmodern yaşam pratiklerinin/kültürünün sınırsız, doyumsuz ve sorumsuzca tüketim teşvikine rağmen, sade, doğal ve kanaatkâr bir yaşama ve dünyanın faniliğine dikkat çeken en önemli faktör olarak varlığını sürdürmektedir. Nitekim postmodernist tüketim formunun insanlık için ontolojinin ötesinde salt maddi gereksinimlere dönük (görece zayıf) yapıda olması, buna karşın dinin, insanlığın ontolojik gereksinimleri karşılamadaki gücü ve işlevi dolayısıyla yeni dinî hareketlerde görüldüğü gibi etkisini arttırabilmesi ve alanını genişletebilmesine imkân tanımaktadır. Bu nedenle 
din, turizm alanlarında görülen tüketim ve haz odaklı postmodernist eğilimlere ve seküler yapılanmalara karşı en güçlü sistemi kendi içinde barındırmaktadır.

\section{Kaynakça}

Akbaba, Atilla - Çavuşoğlu, Fatih. "Helal Otel Kavramı ve Türkiye'de Helal Otel Sertifikasvonu”. Uluslararası Güncel Turizm Araștırmaları Dergisi 1/1 (Haziran 2017), 48-58. https://doi.org/ 10.30625/ijctr.309145

Anderson, Perry. Postmodernitenin Kokenleri. çev. Sungur Savran. İstanbul: İletişim Yayınları, 2009.

Ateş, Sümeyye. Dindarlı ve Tüketim Algıları Arasındaki İlişki. Konya: Necmettin Erbakan Üniversitesi, Sosyal Bilimler Enstitüsü, Yüksek Lisans Tezi, 2019.

Aygül, Hasan Hüseyin - Öztürk, Özgür. "Dini Çoğulculuk ve Kamusal Alanda Dindar Tüketim Kültürü”. Moment Dergisi 3/1 (Haziran 2016), 190-206. https://doi.org/10.17572/mj2016.1.190206

Baltacı, Ali. "Muhafazakâr Tüketim: Türkiye'de Muhafazakârlı̆̆ın Tüketim Eksenli Dönüşüm Dinamikleri”. Harran Üniversitesi İlahivat Fakültesi Dergisi 24/42 (Aralık 2019), 111-135. https://doi.org/10.30623/harranilahiyatdergisi.620817

Baudrillard, Jean. Tüketim Toplumu. çev. Hazal Deliceçaylı - Ferda Keskin. İstanbul: Ayrıntı Yayınları, 3. Basim, 2008.

Best, Steven - Kellner, Douglas. Postmodern Teori. çev. Mehmet Küçük. İstanbul: Ayrıntı Yayınları, 1998.

Bilgin, Vejdi. “Popüler Kültür ve Din: Dindarlığın Değișen Yüzü”. Uludağ Üniversitesi Illahiyat Fakültesi Dergisi 12/1 (Ocak 2003), 193-214.

Bilici, Mücahit. “İslam'ın Bronzlaşan Yüzü: Caprice Hotel Örnek Olayı”. İslam’n Yeni Kamusal Yüzleri. ed. Nilüfer Göle. 216-236. İstanbul: Metis Yayınları, 2000.

Blackwell, Ruth. "Motivations for Religious Tourism, Pilgrimage, Festivals and Events". Religious Tourism and Pilgrimage Festivals Management: An International Perspective. ed. Razaq Raj - Nigel D. Morpeth. 35-47. UK-USA: CAB International, 2007.

Cohen, Erik. "Pilgrimage Centres: Concentric and Excentric". Annals of Tourism Research 19/1 (April 2002), 33-50. https://doi.org/10.1016/0160-7383(92)90105-X

Collins-Kreiner, Noga - Kliot, Nurit. "Pilgrimage Tourism in the Holy Land: The behavioul Characteristics of Christian Pilgrims". GeoJournal 50 (January 2000), 55-67. https://doi.org/10.1023/ A:1007154929681

Çapcıoğlu, İhsan. "Küreselleşme, Kültür ve Din". Ankara Üniversitesi İlahiyat Fakültesi Dergisi 49/2 (Ağustos 2008), 153-183. https://doi.org/10.1501/Ilhfak_0000000973

Dal, Nil Esra - Topay, Gülnihal. "Muhafazakâr Tüketicilerin Helâl Turizme Bakışı". Avrasya Sosyal ve Ekonomi Araștırmaları Dergisi 5/12 (Aralık 2018), 260-280.

Debord, Guy. Gösteri Toplumu ve Yorumlar. çev. Ayşen Ekmekçi - Okşan Taşkent. İstanbul: Ayrıntı Yayınları, 1996.

Demirezen, İsmail. Tüketim Toplumu ve Din. İstanbul: Dem Yayınları, 2015.

DİB, Diyanet İşleri Başkanlığı. Türkiye'de Dinî Hayat Araştırması. Ankara: Diyanet İşleri Başkanlığı Yayinları, 2014.

Digance, Justine. "Pilgrimage at Contested Sites". Annals of Tourism Research 30/1 (January 2003), 143159. https://doi.org/10.1016/S0160-7383(02)00028-2

Dikici, Erkan - Sağır, Adem. “Antalya'da İnanç Turizminin Sosyolojik Çözümlenmesi: Demre-Myra Örneği”. Karamanoğlu Mehmetbey Üniversitesi Sosyal ve Ekonomik Araștırmalar Dergisi 14/22 (Mart 2012), 35-43.

Din, Kadir H. "Islam and Tourism: Patterns, Issues, and Options". Annals of Tourism Research 16/4 (1989), 542-563. https://doi.org/10.1016/0160-7383(89)90008-X 
Doğanay, Hayati. Türkiye Turizm Coğrafyası. Konya: Çizgi Kitabevi, 2001.

Echchaibi, Nabil. "Mecca Cola and Burqinis: Muslim Consumption and Religious İdentities". Religion, Media and Culture: A Reader. ed. Lynch Gordon-Jolyon Michell. 1-10. New York: Routledge, 2011.

El-Gohary, Hatem. "Halal Tourism, Is It Really Halal". Tourism Management Perspectives 19/B (July 2016), 124-130. https://doi.org/10.1016/j.tmp.2015.12.013

Gazneli, Didem - Sofuoğlu Kılıç, Nilgün. "Din Eksenli Tüketimin Yeni Medyadaki Görünümleri: Tüketim Kültürü Bağlamında Bir Değerlendirme”. Medva ve Din Araștırmaları Dergisi 3/2 (Aralık 2020), 197-216. https://doi.org/10.47951/mediad.837857

Göka, Şenol. İnsan ve Mekân. İstanbul: Pınar Yayınları, 2001.

Göle, Nilüfer. Seküler ve Dinsel: Aşınan Sinırlar. çev. Erkal Ünal. İstanbul: Metis Yayınları, 2012.

Görmez, Mehmet. “Diyanet İşleri Başkanı Mehmet Görmez'den Uyarı”. Beyazgündem. Erişim 12 Ocak 2021. https://www.beyazgundem.com/gundem/diyanet-isleri-baskani-mehmet-gormezden-uyari- h211.html

Güler, Şevki. Turizm Sosyolojisi. Ankara: Turizm Bakanlı̆̆ı Yayınları, 1978.

Haenni, Patrick. Piyasa İslam’ (İslam Suretinde Neoliberalizm). çev. Levent Ünsaldı. Ankara: Özgür Üniversite Kitaplığı, 2011.

Halis, Muhsin - Korkutata, Abdulmenaf. "Helal Helal midir? Turizmde Standartlar, Uygulamalar ve Sorunlar”. Van Yüzüncü Yıl Üniversitesi Sosyal Bilimler Enstitüsü Dergisi İslam Kongresi Özel Sayısı (2018), 195-213.

Harvey, David. Postmodernliğin Durumu. çev. Sungur Savran. İstanbul: Metis Yayınları, 1999.

Iheanacho, Ngozi Nneji. "Nigerian Praxis of Religious Tourism and Pilgrimage Motivations in The Globalizing Word”. Ciencias da Religiao: Historia e Sociedade 13/1 (September 2015), 259-284.

Jafari, Aliakbar - Süerdem, Ahmet. "An Analysis of Material Consumption Culture in the Muslim Word”. Marketing Theory 12/1 (March 2012), 61-79. https://doi.org/10.1177/1470593111424184

Kanık, Cengiz. “Abdurrahman Gazi Türbesi ve Psiko-Sosyal Etkileri”. Siirt Üniversitesi Sosyal Bilimler Enstitüsü Dergisi 6/11 (Haziran 2018), 137-148.

Kamenidou, Irene - Vourou, Rafaela. "Motivation Factors for Visiting Religious Sites: The Case of Lesvos Island”. European Journal of Tourism Research 9 (January 2015), 78-91.

Kaynak, İbrahim Hakkı. “İnanç Turizminin Medeniyetler Arası İşbirliğine Etkileri: Türkiye Örneği”. Selçuk Üniversitesi Sosyal Bilimler Meslek Yüksekokulu Dergisi 13/1-2 (Mayıs 2010), 119-126.

Koç, Bekir. "Tüketim Toplumunda Metalaştırılan Dini Yeniden Okuma Önerisi: Bireyin Dine Yabancllaşması Üzerine Bir Giriş”. Bingöl Üniversitesi İlahiyat Fakültesi Dergisi 1/13 (Haziran 2019), 141167.

Köksal, Yelda - Karabulut, Kerem. “İnanç Turizmi ve Bölgesel Kalkınmaya Etkisi Ağrı İli Örneği”. Ağr İbrahim Cecen Üniversitesi Sosval Bilimler Enstitüsü Dergisi 5/1 (Nisan 2019), 83-104. https://doi.org/10.31463/aicusbed.523594

Kömeçoğlu, Uğur. "Islamic Patterns of Consumption". Cultural Changes in the Turkic World. ed. Filiz Kıral vd. 57-69. Würzburg: Ergon-Verlag, 2007.

Köroğlu, Cemile Zehra. “Tüketim Kültürü ve Din Olgusu Üzerine Uygulamalı Bir Araştırma”. Toplum Bilimleri Dergisi 8/15 (Ocak 2014), 85-120.

Küçükşen, Kübra. Dindarların Para ile İmtihanı Holding Tecrübesi. Konya: Çizgi Kitabevi, 2012.

Mardin, Şerif. Türkiye'de Toplum ve Siyaset. der. Mümtaz'er Türköne - Tuncay Önder. İstanbul: İletişim Yayınları, 1990.

Meriç, Sağbetullah - Bozkurt, Öznur. “İslam Dünyasının En Büyük Tarihi-Anıt Mezarlığının (Selçuklu Mezarlı̆̆ı) Kültür ve İnanç Turizmi Kapsamında Değerlendirilmesi”. Nişantaşı Üniversitesi Sosyal Bilimler Dergisi 4/1 (Haziran 2016), 117-134.

Mokhlis, Safiek. "Revelancy and Measurement of Religiositv in Consumer Behavior Research". International Business Research 2/3 (June 2009), 75-84. https://doi.org/10.5539/ibr.v2n3p75 
Okumuş, Ejder. Dinin Meşrulaştırma Gücü. İstanbul: Ark Kitapları, 2005.

Okumuş, Ejder. Gösterişçi Dindarlı. İstanbul: Ark Yayınları, 2. Basım, 2005.

Okumuş, Ejder. Zamanın Toplumsal Gerçekliği. İstanbul: Ark Kitapları, 2011.

Okumuş, Ejder. Boş Zamanlar Kitabı. İstanbul: Akis Kitap, 2013.

Okumuş, Ejder. Din Sosyolojisi. Ankara: Maarif Mektepleri Yayınları, 2018.

Özbolat, Abdullah. “Tüketim Bağlamında Dindarlığın Dönüşümü”. Birikimdergisi. Erişim 9 Ocak 2021. https://birikimdergisi.com/guncel/1127/tuketim-baglaminda-dindarligin-donusumu\#_ftnref4

Özbolat, Abdullah. "Postmodern Dünyada Din: Yaygınlaşan Dinsellik, Yüzeyselleşen Dindarlik”. İslâmî Araştırmalar Dergisi 28/3 (Aralık 2017), 265-278.

Öztürk, Esra. Tüketim Kültüründe Müslümanların İtikadî ve Ahlâkî Problemleri. Bursa: Bursa Uludağ Üniversitesi, Sosyal Bilimler Enstitüsü, Yüksek Lisans Tezi, 2019.

Perşembe, Erkan. “Modernlik ve Postmodernlikte Din Problemi”. Ondokuz Mayıs Üniversitesi İlahiyat Fakültesi Dergisi 14/ 14-15 (Haziran 2003), 159-181.

Pişkin, Mücahit. “Tüketim Toplumu'nda Din ve Dinî Değerler: Lüks Hac ve Umre Örnek Olavı”. İnsan ve Toplum 6/2 (Aralık 2016), 131-154. https://doi.org/10.12658/human.society.6.12.M0195

Poyraz, Hasret - Oktay, Kutay. "Helâl Konseptli Otellerde Tutundurma Stratejilerine Yönelik Bir Değerlendirme”. Uluslararası Türk Dünyası Turizm Araştırmaları Dergisi 2/1 (Bahar 2017), 101111.

Rafiki, Ahmad - Abdul Wahab, Kalsom. "Islamic Values and Principles in the Organization: A Review of Literature". Asian Social Science 10/9 (April 2014), 1-7. https://doi.org/10.5539/ass.v10n9p1

Razalli, Mohd Rizal vd. "Developing a Moder for Islamic Hotels: Evaluating Opportunities and Challenges". International Conference on Knowledge, Cultur and Society 2012 (ICKCS 2012), Jeju Island, South Korea: 29-30 June 2012, 91-95.

Rinschede, Gisbert. "Forms of Religious Tourism”. Annals of Tourism Research 19 (January 1992), 5167. https://doi.org/10.1016/0160-7383(92)90106-Y

Sargın, Sevil. “Yalvaç’ta İnanç Turizmi”. Furat Üniversitesi Sosyal Bilimler Dergisi 16/2 (Temmuz 2006), 1-18.

Senemoğlu, Olkan. “Tüketim, Tüketim Toplumu ve Tüketim Kültürü: Karşılaștırmalı Bir Analiz”. İnsan ve İnsan 4/12 (Nisan 2017), 66-86. https://doi.org/10.29224/insanveinsan.313030

Sever, Ramazan. “Battalgazi (Eski Malatya) İlçesinin Kültürel Peyzajinda Tarih ve İnanç Turizmi”. International Journal of Human Sciences 13/1 (Nisan 2016), 2135-2157. https://doi.or/10.14687/ ijhs.v13i1.3617

Seyidov, İlgar. “Tüketicilerin Davranışlarında Sekillendirici Bir Faktör Olarak İslami Bağlllık”. Selçuk İletişim 9/1 (Ağustos 2015), 388-409. https://doi.org/10.18094/si.22670

Sezgin, Orhan Mesut. Genel Turizm. Ankara: Tutibay Yayınları, 1995.

Shackley, Myra. "Management Challenges for Religion-Based Attractions". Managing Visitor Attractions: New Directions, ed. Alan Fyall vd. 159-171. Oxford: Elsevier Butterworth-Heinemann, 2003.

Smith, Valene L. "Introduction: The quest in quest". Annals of Tourism Research 19/1 (January 1992), 1-17. https://doi.org/10.1016/0160-7383(92)90103-V

Solmaz, Seyit Ahmet. “Turizmin Doğuşu: Sosyolojik Bir Olgu Olarak Turizm Nasıl Ortaya Çıktı?". Journal of Social, Humanities and Administrative Sciences 5/19 (Ekim 2019), 867-882. https://doi.org/10.31589/JOSHAS.173

Subaşı, Necdet. Gündelik Hayat ve Dinsellik. İstanbul: İz Yayınları, 2004.

Sungur, Erol. "Postmodern Tüketim Kültürü ve Değişen Müslüman Kimliği”. Recep Tayyip Erdoğan Üniversitesi İlahiyat Fakültesi Dergisi 3/5 (Aralık 2014), 131-165.

Sungur, Erol. Postmodern Tüketim Anlayışında Dindar Yaşam Biçimleri. Rize: Recep Tayyip Erdoğan Üniversitesi, Sosyal Bilimler Enstitüsü, Doktora Tezi, 2016. 
Sungur, Erol. “Postmodern Tüketim ve Dindarın Seçkinlik (Elitlik) Göstergeleri”. Hitit Üniversitesi Sosyal Bilimler Enstitüsü Dergisi 10/2 (Aralık 2017), 1277-1298. https://doi.org/10.17218/hititsosbil.334618

Tekin, Mustafa. "Postmodernizmin "Din" Sorunu". Milel ve Nihal 12/2 (Temmuz 2015), 7-24. https://doi.org/10.17131/milelnihal.13971

Tekin, Ömer Akgün. “İslami Turizm: Dünya'daki ve Türkiye’deki Genel Durum Üzerine Bir İnceleme”. Uluslararası Sosyal Araştirmalar Dergisi 7/29 (Ocak 2014), 750-766.

Tekin, Ömer Akgün - Yılmaz, Esra. "İslami Turizm Konseptinde Hizmet Veren Konaklama İşletmeleri Üzerine Bir İnceleme”. Uluslararası Sosyal Araștırmalar Dergisi 9/42 (Şubat 2016), 2046-2058. https://doi.org/10.17719/jisr.20164216313

Tomasi, Luigi. "Homo Viator: From Medieval Pilgrimage to Religious Tourism via the Journey”. From Medieval Pilgrimage to Religious Tourism: The Social and Cultural Ecnomics of Piety. ed. William H. Swalos - Luigi Tomasi. 1-24.Westport: ABC-CLIO, February 2002.

Toskay, Tunca. Turizm: Turizm Olayına Genel Yaklaşım. İstanbul: Der Yayınları 1989.

Triantafillidou, Amalia vd. "Pilgrimages: The "Promised land" for Travel Agents?". International Journal ofContemporary Hospitality Management 22/3 (April 2010), 382-398. https://doi.org/10.1108/ 09596111011035963

Tuna, Muammer - Yanardă̆, Aslıhan Aykaç. Turizm Sosyolojisi. ed. Muammer Tuna. Eskişehir: Anadolu Üniversitesi Yayınları, 4. Basım, 2014.

Türker, Nuray vd. "Dini Mekanları Ziyaret Eden Turistlerin Seyahat Motivasyonları: Kastamonu İlinde Bir Uygulama”. Safran Kültür ve Turizm Araştırmaları Dergisi 2/1 (Nisan 2019), 111-132.

Usta, Öcal. Genel Turizm. İzmir: Anadolu Matbaacılık, 2001.

Veblen, Thorstein. Aylak Sinıf. çev. İnci User. İstanbul: Marmara Üniversitesi Teknik Eğitim Fakültesi Matbaası, 1995.

VGM, Vakıflar Genel Müdürlüğü. “Yurt İçi Taşınmaz Vakıf Kültür Varlıklarına Örnekler”. Erişim 10 Ocak 2021. https://www.vgm.gov.tr/faaliyetler/restore-edilen-tasinmaz-vakif-kultur-varliklari/yurt-ici-tasinmaz-vakif-kultur-varliklarina-ornekler

Weidenfeld, Adi - Ron, Amos S. "Religious Needs in the Tuourism Industry". Anatolia: International Journal of Tourism and Hospitality Research 19/2 (December 2008), 357-361. https://doi.org/ 10.1080/13032917.2008.9687080

Wright, Kevin. "Religious Tourism, a new area, a dynamic endustry". Leisure Group Travel Special Edition (November 2007), 8-16.

Yavuz, M. Hakan. Modernleşen Müslümanlar. çev. Ahmet Yıldız. İstanbul: Kitap Yayınevi, 2008.

Yeşiltaş, Mehmet vd. “Otel Seçiminde Dini Hayat Tarzlarının Etkisi”. Elektronik Sosyal Bilimler Dergisi 11/39 (Kış 2012), 193-217.

Yılmaz, Emre. “Türbe Ziyaretlerinin Sebepleri ve Fert Üzerindeki Etkileri: Bilecik Örneği”. Akdeniz İnsani Bilimler Dergisi 6/2 (Aralık 2016), 531-552. https://doi.org/10.13114/MJH.2016.314

Yılmaz, Levent - Güler, Mehmet Emre. “Türkiye'de Muhafazakâr Değerler Bağlamında Turizm ve Tatil Algısındaki Değisme”. Uluslararası Güncel Turizm Araştırmaları Dergisi 1/1 (Haziran 2017), 17-25. https://doi.org/10.30625/ijctr.316598 